Prepared in cooperation with the U.S. Department of the Army Environmental and Natural Resources Management Office of the U.S. Army Signal Center and Fort Gordon

\title{
Assessment of Soil-Gas and Groundwater Contamination at the Gibson Road Landfill, Fort Gordon, Georgia, 2011
}

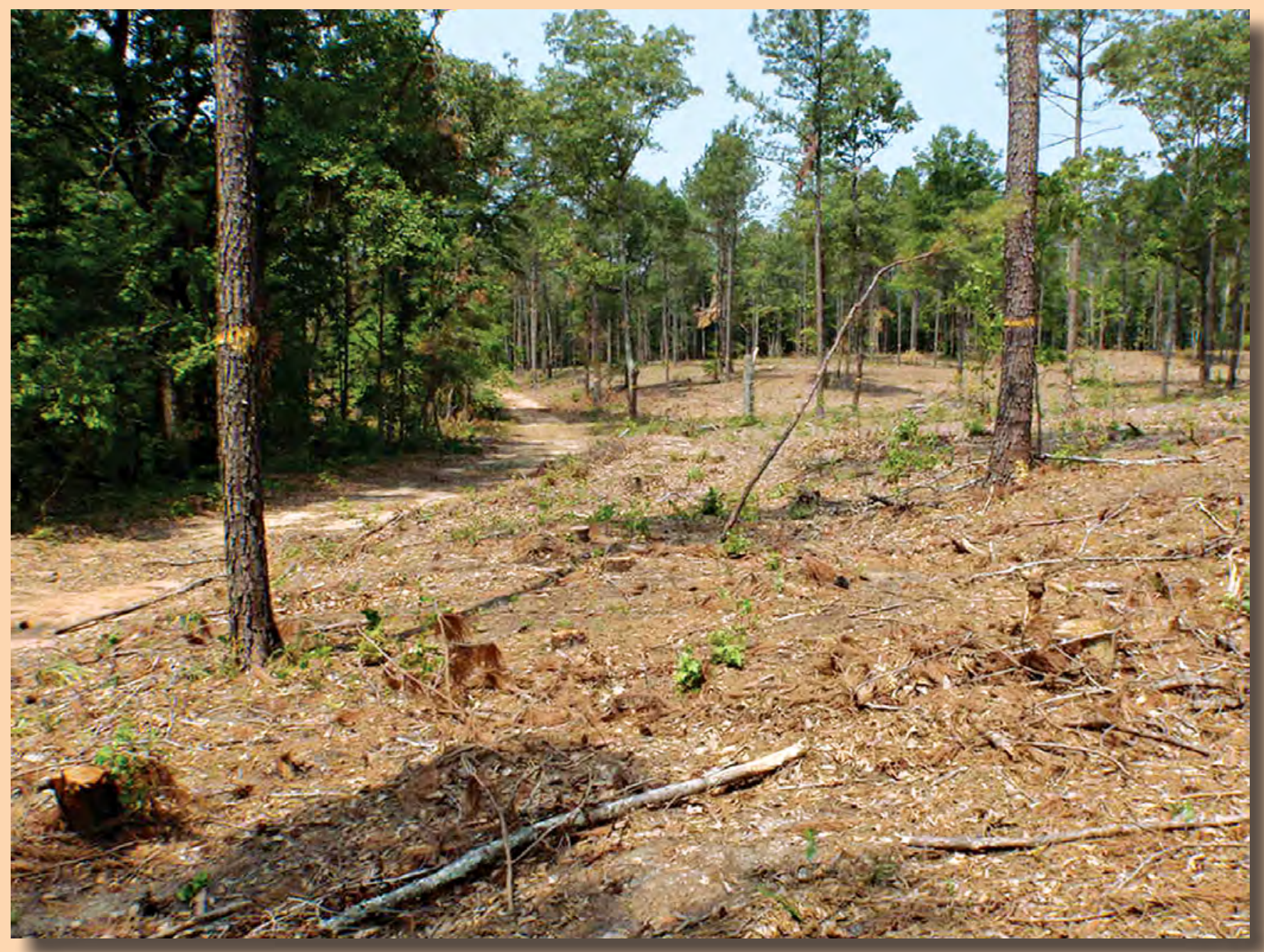

Open-File Report 2012-1128

U.S. Department of the Interior

U.S. Geological Survey 
Cover photo shows access road along northwestern side of wetland and partially cleared land between wetland and Gibson Road landfill. Photo by W. Fred Falls, USGS.; 


\section{Assessment of Soil-Gas and Groundwater Contamination at the Gibson Road Landfill, Fort Gordon, Georgia, 2011}

By W. Fred Falls, Andral W. Caldwell, Wladmir G. Guimaraes, W. Hagan Ratliff, John B. Wellborn, and James E. Landmeyer

Prepared in cooperation with the

U.S. Department of the Army Environmental and Natural Resources Management Office of the U.S. Army Signal Center and Fort Gordon

Open-File Report 2012-1128 


\title{
U.S. Department of the Interior \\ KEN SALAZAR, Secretary \\ U.S. Geological Survey \\ Marcia K. McNutt, Director
}

\author{
U.S. Geological Survey, Reston, Virginia: 2012
}

For more information on the USGS - the Federal source for science about the Earth, its natural and living resources, natural hazards, and the environment, visit http://www.usgs.gov or call 1-888-ASK-USGS.

For an overview of USGS information products, including maps, imagery, and publications, visit http://www.usgs.gov/pubprod

To order this and other USGS information products, visit http://store.usgs.gov

Any use of trade, product, or firm names is for descriptive purposes only and does not imply endorsement by the U.S. Government.

Although this report is in the public domain, permission must be secured from the individual copyright owners to reproduce any copyrighted materials contained within this report.

Suggested citation:

Falls, W.F., Caldwell, A.W., Guimaraes, W.G., Ratliff, W.H., Wellborn, J.B., and Landmeyer, J.E., 2012, Assessment of soil-gas and groundwater contamination at the Gibson Road landfill, Fort Gordon, Georgia, 2011: U.S. Geological Survey Open-File Report 2012-1128, 27 p. (also available at http://pubs.usgs.gov/ofr/2012/1128/. 


\section{Contents}

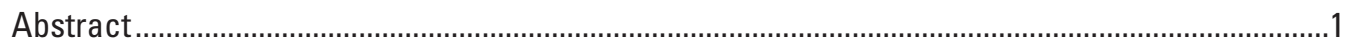

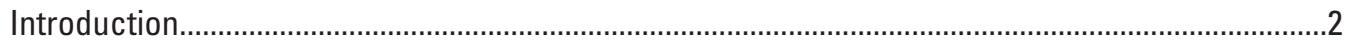

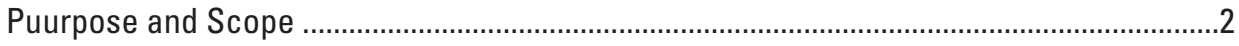

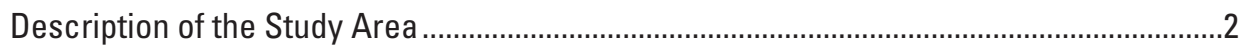

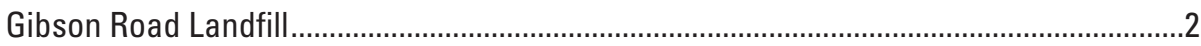

Soil-Gas and Groundwater Assessment.......................................................................

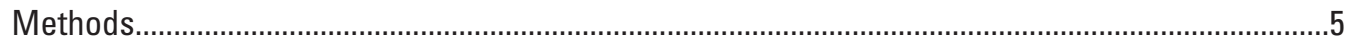

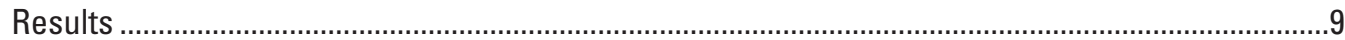

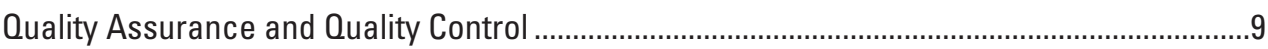

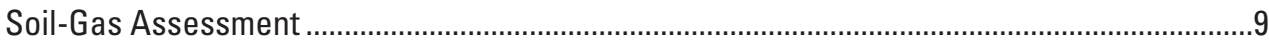

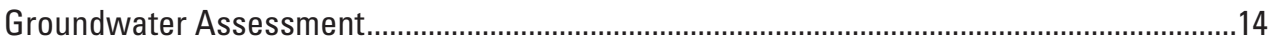

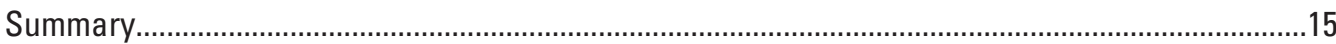

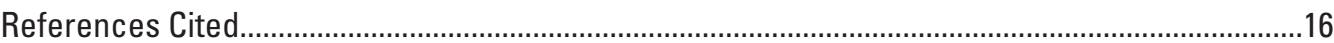

\section{Figures}

1. Map showing the locations of Fort Gordon, the Gibson Road landfill, the monitoring wells, and the study area, Richmond County, Georgia, 2011 ............................

2. Map showing the locations of passive samplers for the soil-gas and groundwater assessments at the Gibson Road landfill,

Richmond County, Georgia, 2011

3. Photographs showing land characteristics of the study area to the southeast of the Gibson Road landfill including the access road along the northwestern side of the wetland and the partially cleared land near the access road, the wooded wetland, the partially wooded area near the southeastern side of the landfill, and the gully near the southeastern side of the landfill, Fort Gordon, Richmond County, Georgia, 2011..

4. Photographs showing a passive sampler prior to installation and in an air-tight vial as received from the laboratory for deployment and shipped to the laboratory for analysis

5. Photographs showing installation of a passive sampler for a soil-gas sampling site, including drilling a borehole in the soil with a stainless steel drill bit attached to a cordless drill, attaching one end of a string to a sampler and the other end to a cork plug, inserting the sampler into the borehole, and sealing the borehole with the cork plug to keep out surface contaminants

6-9. Photographs and aerial site maps showing locations and identification numbers

for passive samplers deployed in the soil and the monitoring wells, and:

6. Ranges of mass in the soil gas and concentration in groundwater for total petroleum hydrocarbons (TPH) at the Gibson Road landfill, Fort Gordon, Georgia, July 25-29, July 26-29, July 29-August 3, and August 8, 2011.

7. Ranges of combined undecane, tridecane, and pentadecane $\left(C_{11}, C_{13}\right.$, and $\left.C_{15}\right)$ as diesel mass in soil gas, and as diesel concentration in groundwater at the Gibson Road landfill, Fort Gordon, Georgia, July 25-29, July 26-29, July 29-August 3, and August 8, 2011 
8. Ranges for combined benzene, toluene, ethylbenzene, and xylene as BTEX mass in the soil gas, and as BTEX concentration in groundwater at the Gibson Road landfill, Fort Gordon, Georgia, July 28-29,

July 29-August 3, and August 8, 2011

9. Ranges for naphthalene, chloroform and perchloroethene as masses in the soil gas, and concentrations of chlorinated compounds in groundwater at the Gibson Road landfill, Fort Gordon, Georgia, July 28-29, July 29-August 3, and August 8, 2011

\section{Tables}

1. Gore identification numbers and location information for passive samplers deployed and recovered in the soil-gas assessment from July 25-29, July 26-29, and July 29-August 3, 2011, and groundwater assessment on August 8, 2011, at the Gibson Road landfill study area, Fort Gordon, Georgia $18-19$

2. Masses for volatile and semivolatile organic compounds and polycyclic aromatic hydrocarbons detected in passive samplers deployed and recovered during the soil-gas assessment in the Gibson Road landfill study area, Fort Gordon, Georgia, July 25-29, July 26-29, and July 29-August 3, 2011

3. Concentrations of volatile and semivolatile organic compounds and polycyclic aromatic hydrocarbons detected in passive samplers deployed and recovered in the water column of monitoring wells in Gibson Road landfill study area, Fort Gordon, Georgia, August 8, 2011 


\section{Conversion Factors and Datums}

\begin{tabular}{|c|c|c|}
\hline Multiply & By & To obtain \\
\hline \multicolumn{3}{|c|}{ Length } \\
\hline inch (in) & 2.54 & centimeter $(\mathrm{cm})$ \\
\hline inch (in) & 25.4 & millimeter $(\mathrm{mm})$ \\
\hline foot $(\mathrm{ft})$ & 0.3048 & meter $(\mathrm{m})$ \\
\hline mile (mi) & 1.609 & kilometer $(\mathrm{km})$ \\
\hline \multicolumn{3}{|c|}{ Area } \\
\hline acre & 4,047 & square meter $\left(\mathrm{m}^{2}\right)$ \\
\hline acre & 0.4047 & hectare (ha) \\
\hline acre & 0.4047 & square hectometer $\left(\mathrm{hm}^{2}\right)$ \\
\hline acre & 0.004047 & square kilometer $\left(\mathrm{km}^{2}\right)$ \\
\hline
\end{tabular}

Horizontal coordinate information is referenced to the North American Datum of 1983 (NAD 83).

\section{Soil-gas units}

$\mu \mathrm{g} \quad$ microgram

$\mu \mathrm{g} / \mathrm{L} \quad$ micrograms per liter

\section{Acronyms and Abbreviation}

$\begin{array}{ll}\text { bdl } & \text { below detection level } \\ \text { BTEX } & \text { benzene, toluene, ethylbenzene, and xylene (total) } \\ \mathrm{C}_{11^{\prime}} \mathrm{C}_{13^{\prime}} \text { and } \mathrm{C}_{15} & \begin{array}{l}\text { undecane, tridecane, and pentadecane (total) } \\ \text { MDL }\end{array} \\ \text { method detection level } \\ \text { methyl tert-butyl ether } \\ \text { PAH } & \text { polycyclic aromatic hydrocarbon } \\ \text { PCE } & \text { perchloroethene (also known as perchloroethylene and tetrachloroethene) } \\ \text { SVOC } & \text { semivolatile organic compound } \\ \text { TCE } & \text { trichloroethene (also known as trichloroethylene) } \\ \text { TPH } & \text { total petroleum hydrocarbons } \\ \text { USEPA } & \text { U.S. Environmental Protection Agency } \\ \text { USGS } & \text { U.S. Geological Survey } \\ \text { VOC } & \text { volatile organic compound }\end{array}$





\title{
Assessment of Soil-Gas and Groundwater Contamination at the Gibson Road Landfill, Fort Gordon, Georgia, 2011
}

\author{
By W. Fred Falls ${ }^{1}$, Andral W. Caldwell', Wladmir G. Guimaraes ${ }^{1}$, W. Hagan Ratliff ${ }^{2}$, \\ John B. Wellborn', and James E. Landmeyer ${ }^{1}$
}

\section{Abstract}

Soil-gas and groundwater assessments were conducted at the Gibson Road landfill in 2011 to provide screening-level environmental contamination data to supplement the data collected during previous environmental studies at the landfill. Passive samplers were used in both assessments to detect volatile and semivolatile organic compounds and polycyclic aromatic hydrocarbons in soil gas and groundwater.

A total of 56 passive samplers were deployed in the soil in late July and early August for the soil-gas assessment. Total petroleum hydrocarbons (TPH) were detected at masses greater than the method detection level of 0.02 microgram in all samplers and masses greater than 2.0 micrograms in 13 samplers. Three samplers located between the landfill and a nearby wetland had TPH masses greater than 20 micrograms.

Diesel was detected in 28 of the 56 soil-gas samplers. Undecane, tridecane, and pentadecane were detected, but undecane was the most common diesel compound with 23 detections. Only five detections exceeded a combined diesel mass of 0.10 microgram, including the highest mass of 0.27 microgram near the wetland. Toluene was detected in only five passive samplers, including masses of 0.65 microgram near the wetland and 0.85 microgram on the southwestern side of the landfill. The only other gasoline-related compound detected was octane in two samplers. Naphthalene was detected in two samplers in the gully near the landfill and two samplers along the southwestern side of the landfill, but had masses less than or equal to 0.02 microgram. Six samplers located southeast of the landfill had detections of chlorinated compounds, including one perchloroethene detection (0.04 microgram) and five chloroform detections ( 0.05 to 0.08 microgram).

\footnotetext{
${ }^{1}$ U.S. Geological Survey, Columbia, South Carolina.

2 Environmental Branch, Fort Gordon, Georgia.

${ }^{3}$ Environmental and Natural Resources Division, Fort Gordon, Georgia.
}

Passive samplers were deployed and recovered on August 8, 2011, in nine monitoring wells along the southwestern, southeastern and northeastern sides of the landfill and downgradient from the eastern corner of the landfill. Six of the nine samplers had TPH concentrations greater than 100 micrograms per liter. TPH concentrations declined from 320 micrograms per liter in a sampler near the landfill to 18 micrograms in a sampler near the wetland. Five of the samplers had detections of one or more diesel compounds but detections of individual diesel compounds had concentrations below a method detection level of 0.01 microgram per liter. Benzene was detected in three samplers and exceeded the national primary drinking-water standard of 5 micrograms per liter set by the U.S. Environmental Protection Agency. The concentrations of benzene, and therefore BTEX, were 6.1 micrograms per liter in the sampler near the eastern corner of the landfill, 27 micrograms per liter in the sampler near the wetland, and 37 micrograms per liter in the sampler at the southern corner of the landfill.

Nonfuel-related compounds were detected in the four wells that are aligned between the eastern corner of the landfill and the wetland. The sampler deployed nearest the eastern corner of the landfill had the greatest number of detected organic compounds and had the only detections of two trimethylbenzene compounds, naphthalene, 2-methyl naphthalene, and 1,4-dichlorobenzene. The two upgradient samplers had the greatest number of chlorinated compounds with five compounds each, compared to detections of four compounds and one compound in the two downgradient samplers. All four samplers had detections of 1,1-dichloroethane which ranged from 42 to 1,300 micrograms per liter. Other detections of chlorinated compounds included trichloroethene, perchloroethene, cis-1,2-dichloroethene, 1,1,1-trichloroethane and chloroform. 


\section{Introduction}

Fort Gordon is a U.S. Department of the Army facility located in east-central Georgia, approximately 10 miles southwest of Augusta, Georgia (fig. 1). Several areas at Fort Gordon have been used for the disposal of waste related to the operation of the fort, including the currently (2012) active Gibson Road landfill near Sandy Run Creek in the central part of Fort Gordon. Volatile organic compounds have been detected during previous investigations in water samples from the groundwater-monitoring wells located inside and outside the perimeter fence of the landfill (Priest and McSwain, 2002).

Soil-gas and groundwater assessments were conducted at the Gibson Road landfill in 2011 to provide screening-level environmental contamination data to supplement the data collected during previous environmental studies at the landfill (fig. 2). The soil-gas and groundwater data of the 2011 assessments are not quantitative as were previously reported waterquality data for water samples, but the sampling sites in the soil-gas assessment are more numerous than the existing monitoring wells and have a broader coverage of the area immediately outside the perimeter fence surrounding the landfill and in the downslope area between the landfill and a nearby unnamed wetland. Passive samplers also were deployed in the water column of nine of the existing monitoring wells to determine the organic compounds in the groundwater.

The assessment of potential environmental effects at the landfill is warranted, because the Gibson Road landfill is located in the outcrop area of the Dublin and Midville aquifer systems, which are water-supply sources for drinking-water wells in the nearby towns of Augusta and Hephzibah, Georgia (Williams, 2007; fig. 1). The assessments are further warranted because the Gibson Road landfill is located near a wetland that drains to Sandy Run Creek (fig. 1). Contaminants in groundwater, surface water, and soil derived from the landfill could affect the local ecology and water quality of the wetland and Sandy Run Creek, and potentially be transported off Fort Gordon into the regional surface-water drainage system.

\section{Purpose and Scope}

The U.S. Geological Survey assessed the presence of volatile and semivolatile organic compounds (VOCs and SVOCs) and polycyclic aromatic hydrocarbons (PAHs) in soil gas and groundwater in the land surrounding the Gibson Road landfill in July and August 2011 (fig. 2). The assessment was completed in cooperation with the U.S. Department of the Army Environmental and Natural Resources Management Office of the U.S. Army Signal Center and Fort Gordon, Georgia.

The sampling sites for the soil-gas assessment were chosen to determine the distribution of VOCs, SVOCs, and PAHs around the landfill and between the landfill and the wetland, because of the close proximity of the landfill to the wetland (fig. 2). A few additional passive samplers were deployed in the field to the southwest of the landfill to assess the presence of VOCs, SVOCs, and PAHs in the soil between the landfill and Sandy Run Creek.

Nine of the thirteen existing wells used to monitor groundwater levels and collect groundwater samples were sampled with the same passive sampler used at the soil-gas sampling sites to determine the presence of organic compounds in the groundwater along the southwestern and northeastern sides of the landfill and southeast of the landfill in the direction of the wetland (fig. 2). The results of the passive samplers are compared to results for soil-gas samplers deployed adjacent to seven of the wells and to water-quality results from the wells reported in a previous investigation (Priest and McSwain, 2002).

This report provides analytical results for the soil-gas and groundwater samplers and maps showing the locations of the most commonly detected contaminants identified in the study area. This report also provides a map showing the locations of less common detections, such as chlorinated compounds, trimethylbenzene, and naphthalene.

\section{Description of the Study Area}

Fort Gordon is located south of the Fall Line in the northern part of the Coastal Plain Physiographic Province near Augusta, Georgia (fig. 1). Fort Gordon is underlain by late Cretaceous and Tertiary geologic strata and is characterized by soils, alluvial sediments, and geologic exposures of unconsolidated sands and semiconsolidated sandstones, and layers of clay that include kaolinite (Hetrick, 1992; Gregory and others, 2001).

Average annual precipitation in the Fort Gordon/Augusta, Georgia, area is approximately 44.5 inches (in.) (Southeast Regional Climate Center at the University of North Carolina, Chapel Hill, N.C., website accessed February 17, 2012, for Augusta WSO Airport, Georgia 090495, http://nc-climate. ncsu.edu/cronos/normals.php?station=090495). With the porous sandy soil and the hilly topography in the study area, perennial creeks and streams in the area of Fort Gordon receive an ample supply of groundwater discharge to maintain streamflows during times of normal precipitation (Faye and Mayer, 1990; Atkins and others, 1996). During the summer of 2011, however, there was no standing water observed in the wetland, which may reflect the seasonality of intermittent flow in parts of the wetland and the lower than normal annual precipitation of 28.6 and 28.2 in. in the Augusta area in 2010 and 2011, respectively.

\section{Gibson Road Landfill}

The Gibson Road landfill is an approximately 35 -acre site located on the southern sides of Gibson Road and Sawmill Road (unpaved) and occupies a topographically high area 


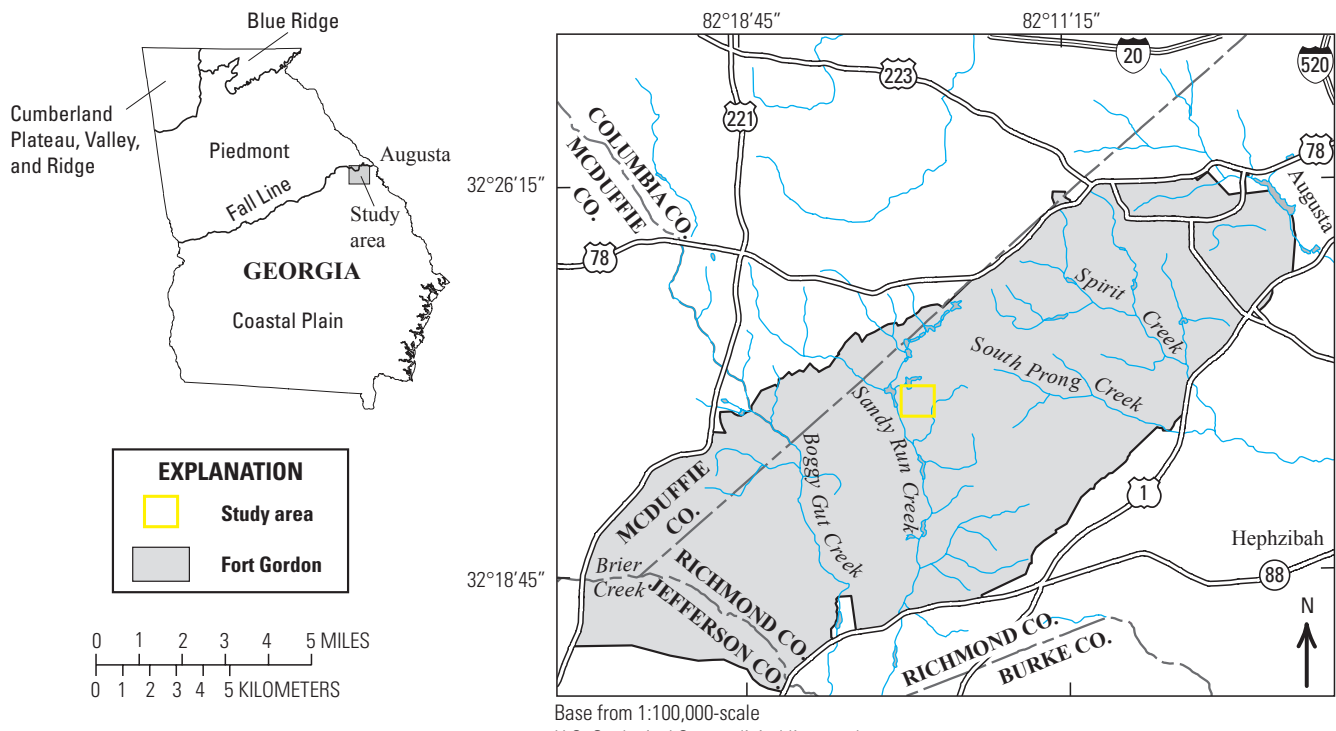

U.S. Geological Survey digital line graph

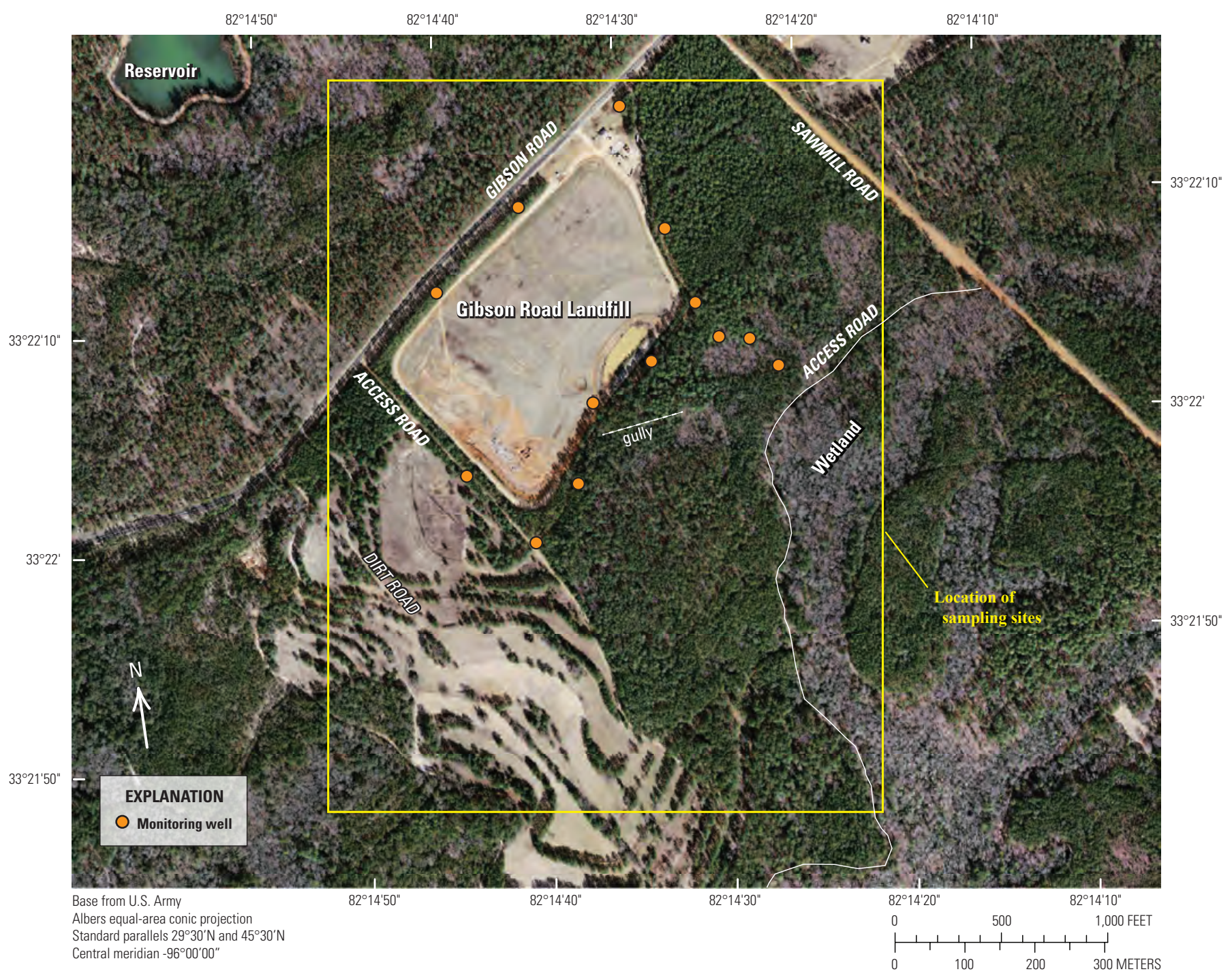

Figure 1. Locations of Fort Gordon, the Gibson Road landfill, the monitoring wells, and the study area, Richmond County, Georgia, 2011. 


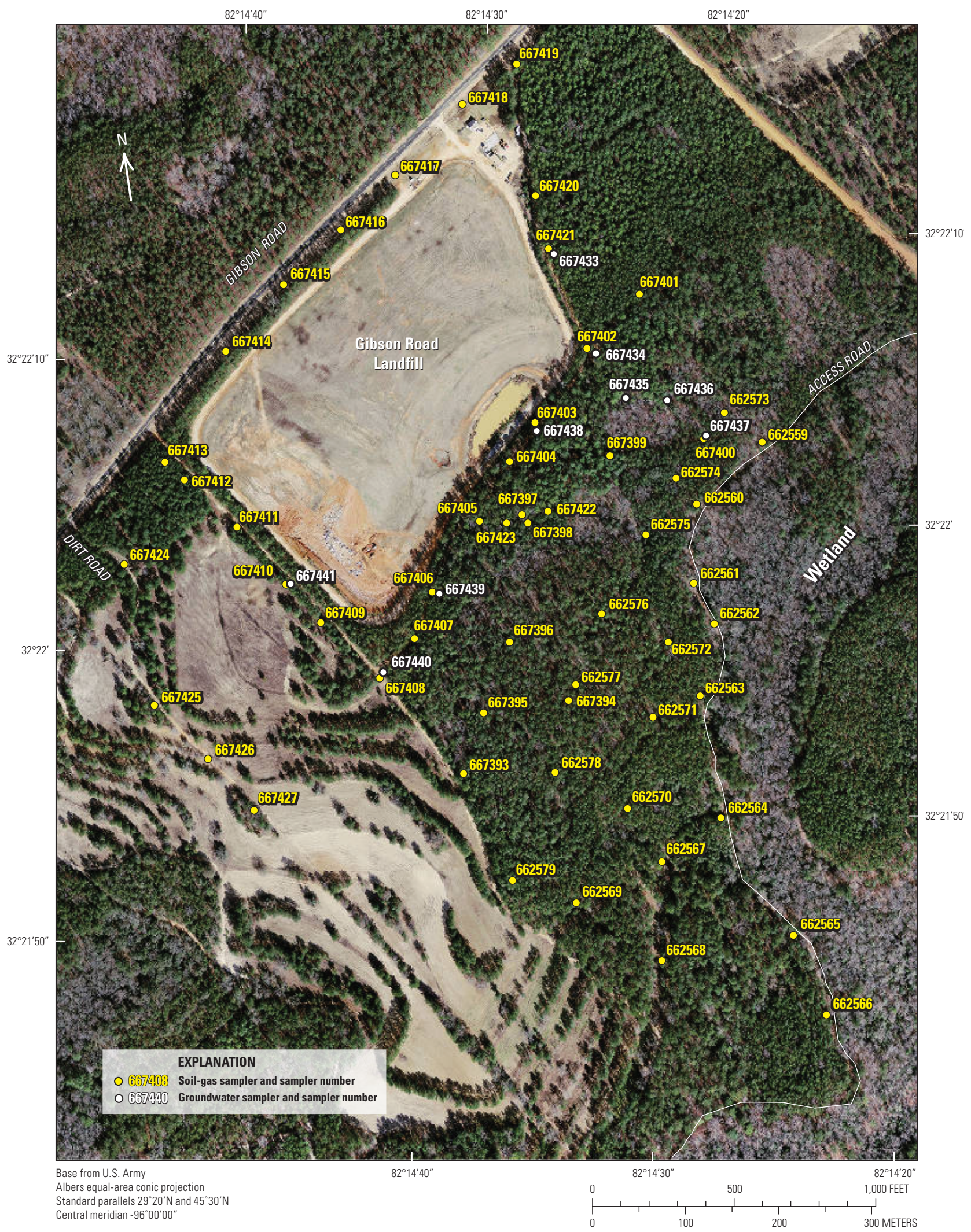

Figure 2. Locations of passive samplers for the soil-gas and groundwater assessments at the Gibson Road landfill, Richmond County, Georgia, 2011. 
relative to the wetland to the southeast, Sandy Run Creek to the southwest, and a small reservoir to the northwest (fig. 1). The landfill is fenced and has a gate to regulate access.

Unpaved access roads parallel the perimeter fence inside and outside the landfill that enables access to the monitoring wells.

The landfill was issued an operating permit in 1985 and operated continuously as an unlined landfill for 26 years prior to the 2011 investigation (Priest and McSwain, 2002). Disposal of household waste began at the northeastern end of the landfill in 1985 and continued into the middle of the landfill through the mid-1990s. Since the mid-1990s, the southwestern part of the landfill has received mainly construction and demolition waste. The northeastern and central parts of the landfill were capped with soil to control infiltration of precipitation and grassed to control erosion, but the southwestern quarter of the landfill is still (2012) open and continues to receive waste (fig. 1).

Overland flow of rainwater inside the fenced area drains across the surface of the capped part of the landfill to a 1-acre retention pond on the southeastern side of the landfill inside the perimeter fence (fig. 1). If enough water accumulates in the retention pond, water drains into an overflow pipe in the center of the pond and is discharged to the adjacent woodland outside the perimeter fence on the southeastern side of the landfill. The southwestern quarter of the landfill receives some overland flow from adjacent parts of the landfill inside the fence and is open to precipitation events.

Monitoring wells were installed along the access roads inside and outside the perimeter fence for a water-quality monitoring program started in 1985 (fig. 1). Additional wells were installed in 1995 in the wooded area downslope of the eastern corner of the perimeter fence (Priest and McSwain, 2002, fig. 1). Groundwater levels were measured in the monitoring wells during June and November 1999. The general direction of groundwater flow is from the northwest to the southeast across the landfill and from the landfill toward the wetland. Organic contaminants were detected in groundwater samples collected in 1998 and 1999 from monitoring wells on the northwestern side of the landfill along Gibson Road, but were detected at higher concentrations for methylene chloride, 1,1-dichloroethane, and 1,1,1-trichloroethane in a well outside the eastern (downgradient) corner of the perimeter fence (Priest and McSwain, 2002).

\section{Soil-Gas and Groundwater Assessment}

The study area chosen for the soil-gas assessment included land on all four sides of the landfill outside the perimeter fence, but mostly consisted of the land between the eastern (downgradient) side of the landfill and the access road adjacent to the wetland (fig. 2). The study area was expanded to include the field to the southwest of the landfill but does not include the land inside the landfill or wetland, or the land to the northwest of Gibson Road. The landfill and soil-gas study area, excluding the wetland, occupies approximately 106 acres at Fort Gordon.
The land between the landfill and the wetland is sloped to the east and southeast and is described as heavily wooded in a previous study (Priest and McSwain, 2002). Prior to the 2011 assessments, however, much of this land between the landfill and the wetland was partially cleared of trees and underbrush. The access road along the edge of the wetland delineates a boundary between the sparsely wooded (cleared) land to the northwest and west of the access road and the still wooded wetland (figs. 1; $3 A, B$ ). Farther upslope toward the landfill, trees were selectively cleared to thin the woodland but this area generally had more trees and underbrush during the 2011 assessment and is steeper than the land closer to the wetland (fig. 3C). An elongated topographic depression (gully) to the southeast is cut into the land surface closer to the eastern side of the landfill and was not disturbed by the clearing of trees (figs. 1 and $3 D$ ).

Passive samplers in the soil-gas assessment were deployed outside the perimeter fence along all four sides of the landfill, between the eastern sides of the landfill and the access road along the edge of the wetland, and in the adjacent field to the southwest of the landfill (fig. 2). Most of the sampling locations were chosen to create a fairly even spacing of the samplers around and downgradient from the landfill. Five of the samplers, however, were intentionally deployed closer together in and adjacent to the gully to evaluate the presence of contaminants associated with this topographically low feature. Four samplers also were deployed 350 to 600 feet (ft) southwest of the landfill to assess the potential for VOCs, SVOCs, and PAHs in the field adjacent to the landfill.

Nine of the thirteen monitoring wells were selected for the groundwater assessment using the passive samplers and represented only a partial coverage in the study area, relative to the passive samplers deployed in the soil-gas assessment (fig. 2). Only wells outside the perimeter fence of the landfill were considered for the study. The wells chosen for the assessment are located along the southwestern, southeastern, and northeastern sides of the landfill or in an area downgradient from the eastern corner of the landfill. Groundwater was collected from some of the wells during a previous study in 1998 and 1999 by a commercial environmental company (Priest and McSwain, 2002).

\section{Methods}

Passive samplers were collected for soil-gas and groundwater assessments of potential organic compounds in the Gibson Road landfill study area (fig. 2; tables 1-3 at end of report). Passive samplers were deployed and collected in the unsaturated soil around and downgradient from the landfill and in the field adjacent to the southwest side of the landfill during late July and early August 2011, and in the water columns of nine existing monitoring wells outside the perimeter fence of the landfill on August 8, 2011. All samplers were analyzed by U.S. Environmental Protection Agency (USEPA)-verified 

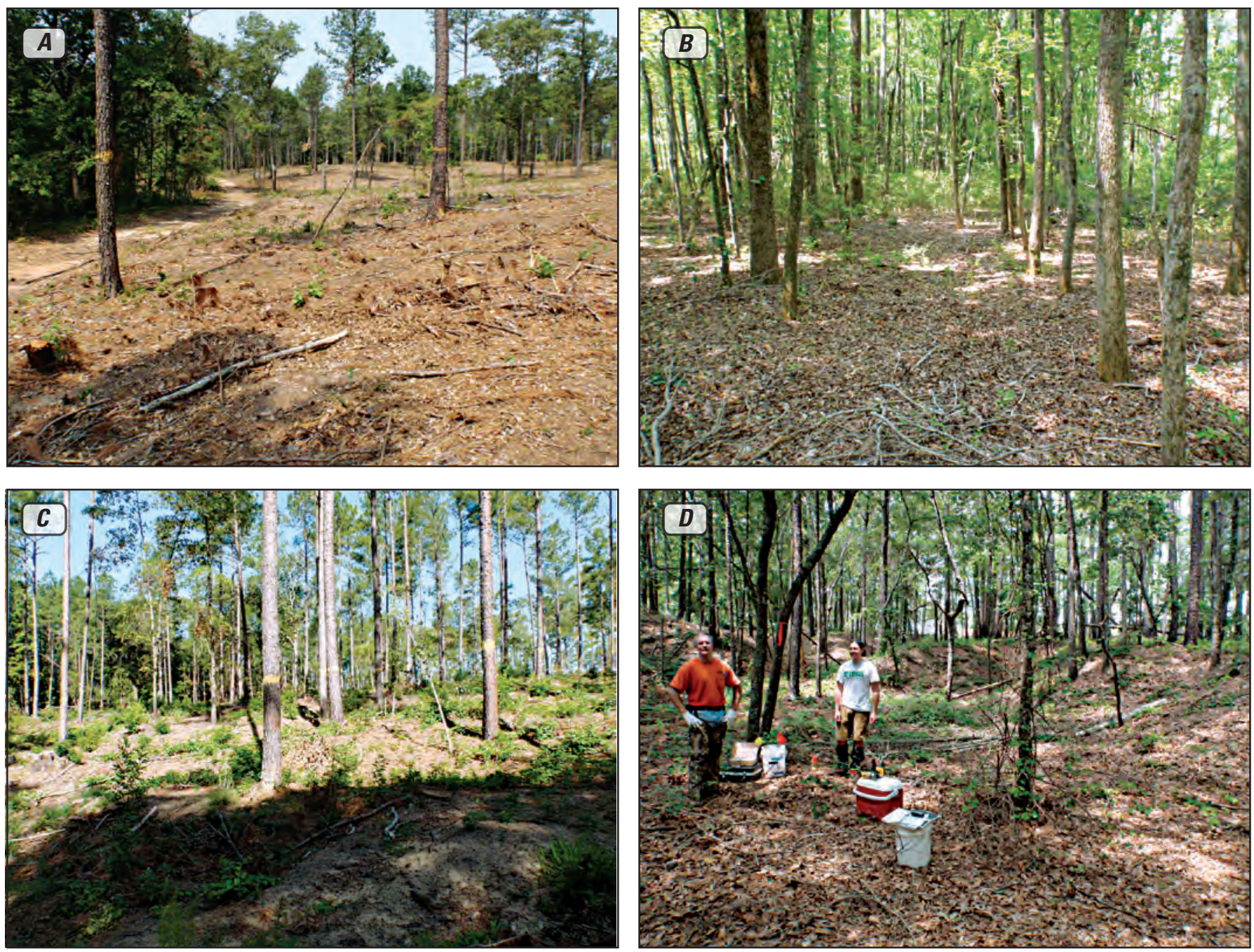

Figure 3. Land characteristics of the study area to the southeast of the Gibson Road landfill, including: $A$, the access road along the northwestern side of the wetland and the partially cleared land near the access road; $B$, the wooded wetland; $C$, the partially wooded area near the southeastern side of the landfill; and $D$, the gully near the southeastern side of the landfill, Fort Gordon, Richmond County, Georgia, 2011

sampling technologies at the W.L .Gore \& Associates Laboratory in Elkton, Maryland, from August 25-29, 2011, (U.S. Environmental Protection Agency, 1998; W.L. Gore \& Associates, Inc., 2004; American Society for Testing and Materials, 2006).

Samples for the soil-gas and groundwater assessments were collected at the Gibson Road landfill by using the GORE ${ }^{\mathrm{TM}}$ passive vapor sampler, a commercially available passive sampler based on GORE-TEX ${ }^{\mathrm{TM}}$ membrane technology (U.S. Environmental Protection Agency, 1998; W.L. Gore \& Associates, Inc., 2004). The passive sampler approach was approved for use at sites at Fort Gordon by the Hazardous Waste Management Branch, Georgia Environmental Protection Department, to collect screening-level data for contaminant assessments (William Powell, P.E., Environmental Engineer, Department of Defense Remediation Unit, oral commun., December 10, 2008).
The passive sampler consists of a proprietary adsorbent medium placed inside a shoestring-shaped GORE-TEX ${ }^{\mathrm{TM}}$ tube (fig. 4A). The proprietary medium can adsorb a wide variety of volatile and semivolatile organic compounds (VOCs/SVOCs), including chlorinated solvents such as trichloroethene (TCE) and perchloroethene (PCE; also known as tetrachloroethene); gasoline-range compounds such as benzene, toluene, ethylbenzene, and xylenes (collectively referred to as BTEX); the gasoline additive methyl tert-butyl ether (MTBE); diesel-range compounds such as undecane, tridecane, and pentadecane (collectively referred to as $\mathrm{C}_{11}, \mathrm{C}_{13}$, and $\mathrm{C}_{15}$ ); and polycyclic aromatic hydrocarbons (PAHs) such as naphthalene (U.S. Environmental Protection Agency, 1998).

Passive results can indicate the presence of particular organic compounds and are a rapid approach for environmental assessment of organic compounds (U.S. Environmental Protection Agency, 1998). The results do not, however, reveal if the detection was derived from free product, residual-phase 

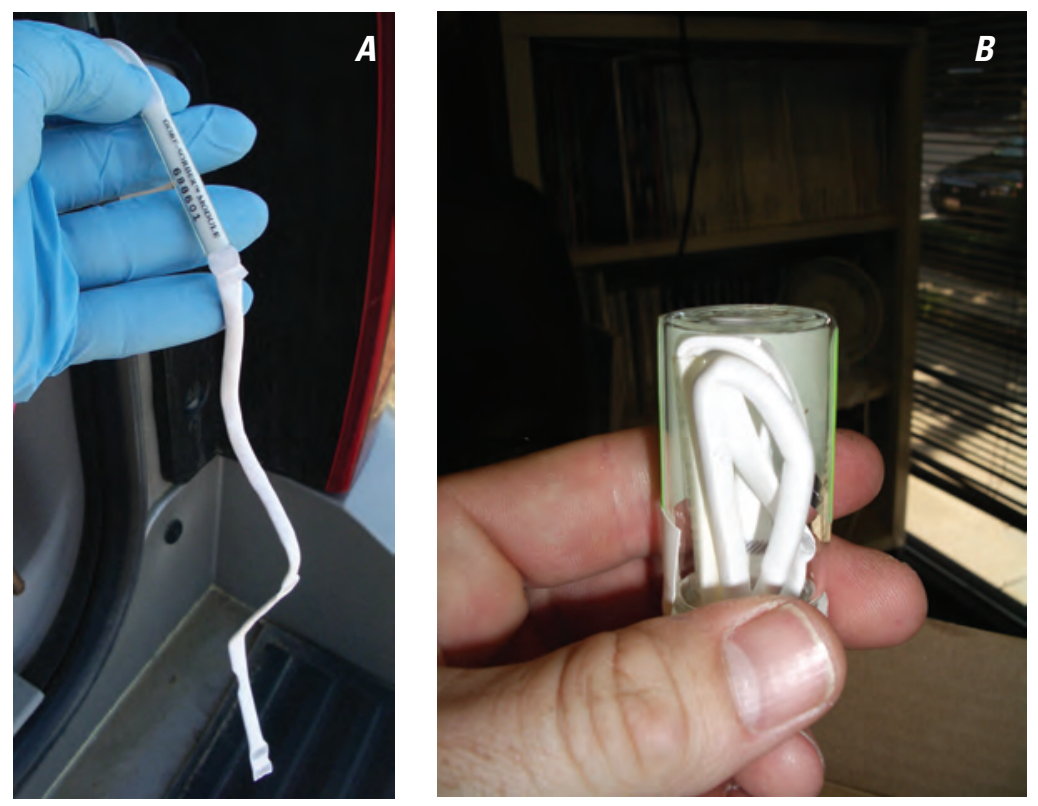

Figure 4. A passive sampler $A$, prior to installation, and $B$, in air-tight vial as received from the laboratory for deployment and shipped to the laboratory for analysis.

compounds adsorbed on soil particles, vapors in the unsaturated zone, or the dissolved compound in shallow and deep groundwater (unless the passive soil-gas sampler is deployed in direct contact with water) (U.S. Environmental Protection Agency, 2000).

In unsaturated soil, higher soil-gas mass in a sampler tends to be related to the presence of residual compounds or free product that is close to the land surface where the sampler is located (U.S. Environmental Protection, 1998). If such source material is located at greater depths, however, the soil-gas mass generally will be lower. A lower value near known sources may be due to various attenuation processes that affect the soil-gas mass prior to detection. In both cases, however, the passive vapor samplers indicate the presence of contaminants.

In the soil-gas study area, sample sites for the passive sampler were created with a stainless steel bit attached to a cordless drill (fig. 5). A 0.5-in-diameter bit was used to drill a 15-in-deep vertical borehole into the soil. A string was attached to a cork plug at one end and the passive sampler at the other end, and was used to lower and suspend the sampler in the borehole. The cork plug was used to seal the borehole at land surface to prevent surface water and ambient land-surface material from entering the borehole. The depth of 15 in. is similar to the depth recommended by the USEPA for soil-gas investigations (U.S. Environmental Protection Agency, 1998). Most of the passive samplers in the soil-gas assessment were deployed on July 25 and recovered on July 29, 2011, after 4 days (96 hours) of exposure to the shallow soil gas. Samplers, including one (667421) next to the well sampled on the northeastern side of the landfill and two (667422 and 667423) deployed in the gully on the southeastern side of the landfill, were deployed on July 26 and recovered on July 29, 2011, after 3 days (72 hours). Four additional samplers (667424
-667427) were deployed near a dirt road in field adjacent to the southwest side of the landfill on July 29 and recovered on August 3, 2011, after 5 days (120 hours).

The same type of passive sampler used in the soil-gas study also was used in the groundwater assessment at the Gibson Road landfill. The wells were not developed specifically for the groundwater assessment, but had been developed before collection of groundwater samples for previous studies. The groundwater level in each well was checked with an electric water-level sensor to determine depth to static groundwater level. A sampler was attached to a weighted string and lowered to a depth of $5 \mathrm{ft}$ below the static groundwater level in each well. The samplers were submerged in the water column for only 30 to 60 minutes because a previous investigation found that contaminants in groundwater can adsorb rapidly on the proprietary medium in a submerged sampler (U.S. Environmental Protection Agency, 2000; Guimaraes and others, 2011). All samplers in the groundwater assessment were deployed and collected on August 8, 2011.

Each passive sampler recovered in the field was placed in its original 20-milliliter $(\mathrm{mL})$ air-tight vial provided by the laboratory and sent to a commercial laboratory (W.L. Gore $\&$ Associates, Inc.) for analysis (fig. 4B). For each period of deployment, 5 to 10 percent of the samplers were kept in the air-tight vials during the deployment and recovery of environmental samplers and were shipped back to the laboratory with the environmental samplers as trip blanks.

All samplers were processed and analyzed at the laboratory by using a modification of USEPA method 8260/8270 (U.S. Environmental Protection Agency, 2006). Prior to analysis, each sampler was processed in an automated thermal desorption unit to produce a gas sample. The gas sample was analyzed by a gas chromatograph equipped with mass-selective detectors. The laboratory analyzed method 

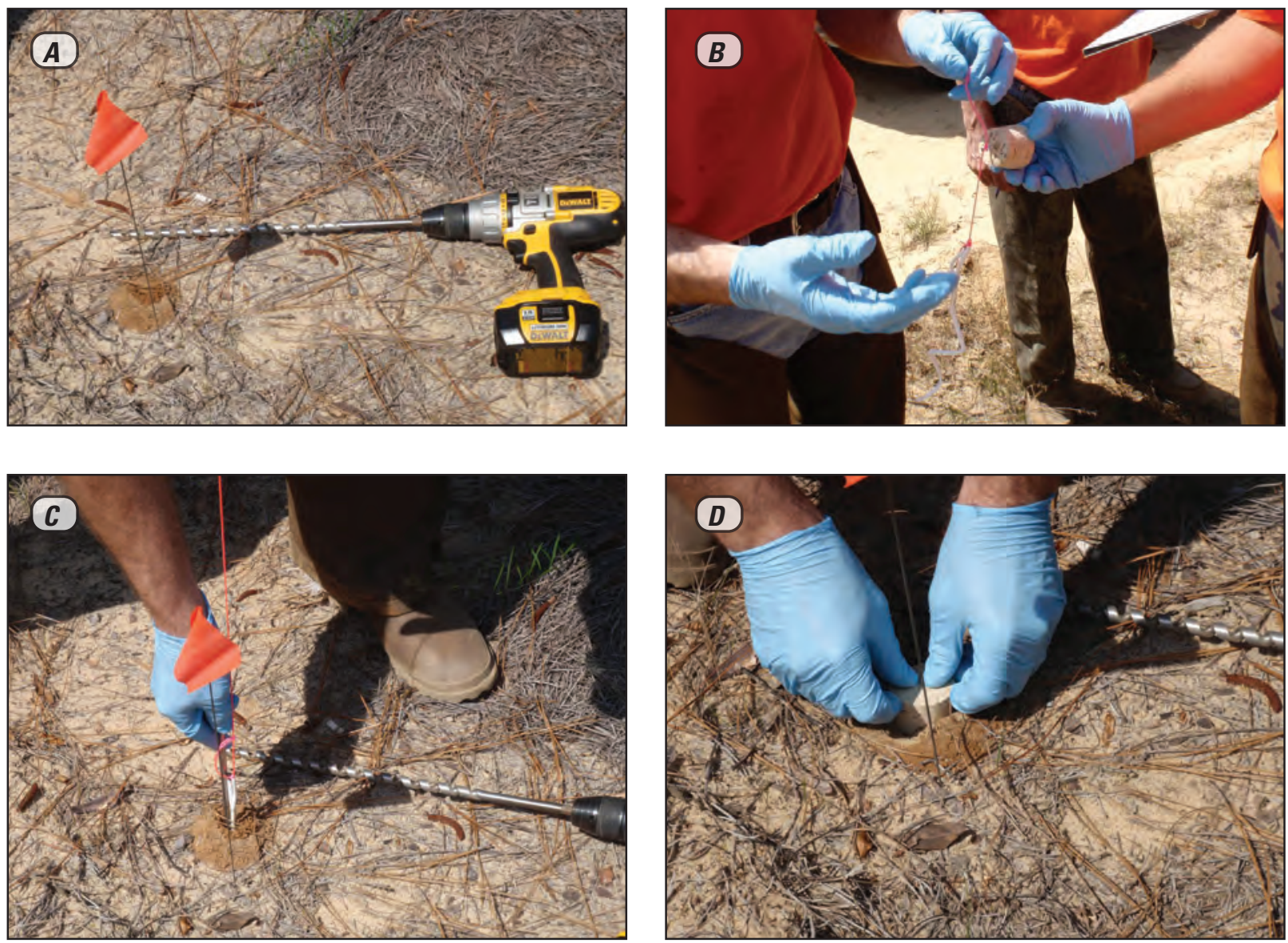

Figure 5. Installation of a passive sampler for a soil-gas sampling site, including: $A$, drilling a borehole in the soil with a stainless steel drill bit attached to a cordless drill; $B$, attaching one end of a string to a sampler and the other end to a cork plug; $C$, inserting the sampler into the borehole; and $D$, sealing the borehole with the cork plug to keep out surface contaminants.

blanks for quality assurance and was in compliance with good laboratory practices and ISO Guide 25 (International Organization for Standardization, 1990). Results are reported as mass in micrograms $(\mu \mathrm{g})$ for the soil-gas assessment and concentration in micrograms per liter $(\mu \mathrm{g} / \mathrm{L})$ for the groundwater assessment. Concentrations in water for each contaminant were calculated using the measured contaminant mass, sampler exposure time to the environment, and compound-specific solute uptake rates based on an average water temperature of 20 degrees Celsius and a water depth of $5 \mathrm{ft}$ (Dayna M. Cobb, Project Manager, W.L. Gore \& Associates, Inc., written commun., September 12, 2011).

The laboratory results provided screening-level data for the assessment of 31 compounds. TPH is a laboratory-derived estimate based on the area under the chromatogram for all aliphatic hydrocarbons, including all gasoline-range $\left(\mathrm{C}_{4}\right.$ to $\left.\mathrm{C}_{10}\right)$ and diesel-range $\left(\mathrm{C}_{10}\right.$ to $\left.\mathrm{C}_{20}\right)$ aliphatic compounds. In addition, results of individual compounds were summed to calculate values for the combined mass in soil gas and combined concentrations in groundwater of benzene, toluene, ethylbenzene, and xylenes (aromatic gasoline-range compounds) as BTEX; undecane, tridecane, and pentadecane $\left(\mathrm{C}_{11}, \mathrm{C}_{13}\right.$, and $\left.\mathrm{C}_{15}\right)$ as diesel; 1,2,4- and 1,3,5-trimethylbenzene (as trimethylbenzene); trans- and cis-1,2-dichloroethene (as 1,2-dichloroethene); and naphthalene and 2-methyl naphthalene (as naphthalene).

The laboratory provided method detection levels (MDL) for each organic compound. The laboratory, however, did not provide MDLs for the five combined values because individual compounds summed as a combined value may have different MDLs. A combined value is considered estimated (E) if the measureable value for at least one of the individual compounds in the combined value is summed with at least one value reported as below its MDL. A value of 0.00 is the reporting format of W.L. Gore \& Associates, Inc., and is used for a combined value if none of the individual compounds summed in the combined value were detected above MDLs and at least one of the individual compounds was reported as below detection level. 


\section{Results}

The detections and the distribution of detections in the Gibson Road landfill study area are evaluated using environmental samplers 662559 to 662579 and 667393 to 667427 as the soil-gas assessment, and environmental samplers 667433 to 667443 as the groundwater assessment (tables 2 and 3, respectively, at end of report). A passive sampler was deployed in the soil next to each of the wells in the groundwater assessment, except for two of the downgradient wells (samplers 667435 and 667436). Results for these seven pairs of samplers are included in the description of the groundwater assessment. The results for the groundwater assessment also are compared to previously published water-quality results for the wells collected in 1998 and 1999 (Priest and McSwain, 2002).

\section{Quality Assurance and Quality Control}

The laboratory reported no detections of organic compounds in the method blanks analyzed with the samplers in the soil-gas and groundwater assessments and no detections in the five trip blanks (667428-667432) associated with the samplers in the soil-gas assessment (tables 2 and 3). The two trip blanks (667442 and 667443) carried to the field during the groundwater assessment, however, did have TPH detections, but the TPH concentrations were reported as below the TPH detection level of $8.3 \mu \mathrm{g} / \mathrm{L}$. One of the trip blanks (667443) carried to the field during the groundwater assessment also had a detection of toluene at a concentration of $4.8 \mu \mathrm{g} / \mathrm{L}$, which exceeded the toluene MDL of $4.1 \mu \mathrm{g} / \mathrm{L}$. There were, however, no detections of toluene in the nine passive samplers for the groundwater assessment, and therefore, the environmental results for toluene did not have to be qualified (censored).

The detection of toluene in trip blank 667443 means that the combined concentration of BTEX in the trip blank also is reported as $4.8 \mu \mathrm{g} / \mathrm{L}$. Three environmental samplers in the groundwater assessment had BTEX detections greater than the BTEX detection in the trip blank, but the BTEX detections in the environmental samplers were due to benzene, not toluene, ethylbenzene, or the xylene compounds. Benzene was not detected in the two trip blanks; therefore, the BTEX detection in the trip blank was not used to qualify (censor) the three BTEX detections in the groundwater assessment.

\section{Soil-Gas Assessment}

A total of 56 samplers were deployed for the soil-gas assessment in the Gibson Road landfill study area (fig. 2). The survey mostly identified detections of TPH and dieselrange compounds, but also identified the presence of BTEX (toluene), PCE, chloroform, and naphthalene in a few samples (table 2).

TPH mass exceeded the MDL of $0.02 \mu \mathrm{g}$ in all 56 samplers and was equal to or exceeded $2.0 \mu \mathrm{g}$ in 13 of the 56 samplers (fig. 6; table 2). The $13 \mathrm{TPH}$ detections greater than $2.0 \mu \mathrm{g}$ were found in samplers located along all sides of the landfill except along Gibson Road, which is upgradient from the landfill. TPH exceeded a mass of $20 \mu \mathrm{g}$ in three samplers located between the landfill and the wetland. The TPH mass in each of the five samplers deployed in the gully located downgradient from the landfill was greater than $0.20 \mu \mathrm{g}$, including $5.7 \mu \mathrm{g}$ in sampler 667397, $8.8 \mu \mathrm{g}$ in sampler 667398, and $27 \mu \mathrm{g}$ in sampler 667422. The largest TPH detection was a mass of $85 \mu \mathrm{g}$ in sampler 662571, which is located downgradient from the landfill within $250 \mathrm{ft}$ of the wetland. The TPH detections along Gibson Road in samplers 667412 to 667419 on the northwestern side of the landfill had TPH masses less than $1 \mu \mathrm{g}$.

TPH was detected from 6.6 to $13 \mu \mathrm{g}$ in three samplers deployed along the southwestern side of the landfill (fig 6; table 2). TPH also was detected from 0.49 to $1.7 \mu \mathrm{g}$ in samplers deployed along a dirt road in the field adjacent to the southwestern side of the landfill.

Diesel was detected in 28 of the 56 samplers, including detections along all four sides of the landfill, downgradient from the landfill toward the wetland, in the gully, and along the dirt road in the field southwest of the landfill (fig. 7; table 2). All three diesel compounds - undecane, tridecane, and pentadecane - were detected, but undecane was the most common diesel compound with 23 detections (table 2). The diesel detections also included 17 detections of tridecane and 8 detections of pentadecane, but 18 of these detections were reported as below detection level. All three diesel compounds have MDLs of $0.01 \mu \mathrm{g}$; therefore, values for the combined mass as diesel were divided into those samplers that had less than $0.10 \mu \mathrm{g}$ (one order of magnitude greater than the MDL) and into those samplers equal to or greater than $0.10 \mu \mathrm{g}$ in figure 7. Only five detections, however, exceeded a combined diesel mass of $0.10 \mu \mathrm{g}$, including $0.12,0.15$ (estimated), and $0.24 \mu \mathrm{g}$ along the southwestern side of the landfill from samplers 667409 to 667411 , and $0.27 \mu \mathrm{g}$ (estimated) in samplers 662571 , and $0.11 \mu \mathrm{g}$ in samplers 667394 southeast of the landfill near the wetland. All other diesel detections were equal to or less than an estimated mass of $0.06 \mu \mathrm{g}$.

BTEX was detected in only five samplers (fig. 8; table 2). Detections of $0.03,0.05$ and $0.06 \mu \mathrm{g}$ were located next to the wetland in sampler 662565 and along the northwestern and southwestern sides of the landfill in samplers 667416 and 667411 , respectively. The other two detections were greater, including $0.65 \mu \mathrm{g}$ in sampler 662571 near the wetland and $0.85 \mu \mathrm{g}$ on the southwestern side of the landfill in sampler 667410. Toluene was the only BTEX compound detected in all five samplers. The only other gasoline-related compound detected in the soil-gas assessment was octane which had a mass of $0.07 \mu \mathrm{g}$ in sampler 667410 and a mass reported as below detection level in sampler 667405 .

Naphthalene was detected in only four samplers (fig. 9; table 2). Two detections of $0.01 \mu \mathrm{g}$ in sampler 667397 and $0.02 \mu \mathrm{g}$ in sampler 667398 were in the gully southeast of the landfill. The other two detections of $0.02 \mu \mathrm{g}$ in sampler 667409 and a mass reported as below detection level in sampler 667411 were along the southwestern side of the landfill. 


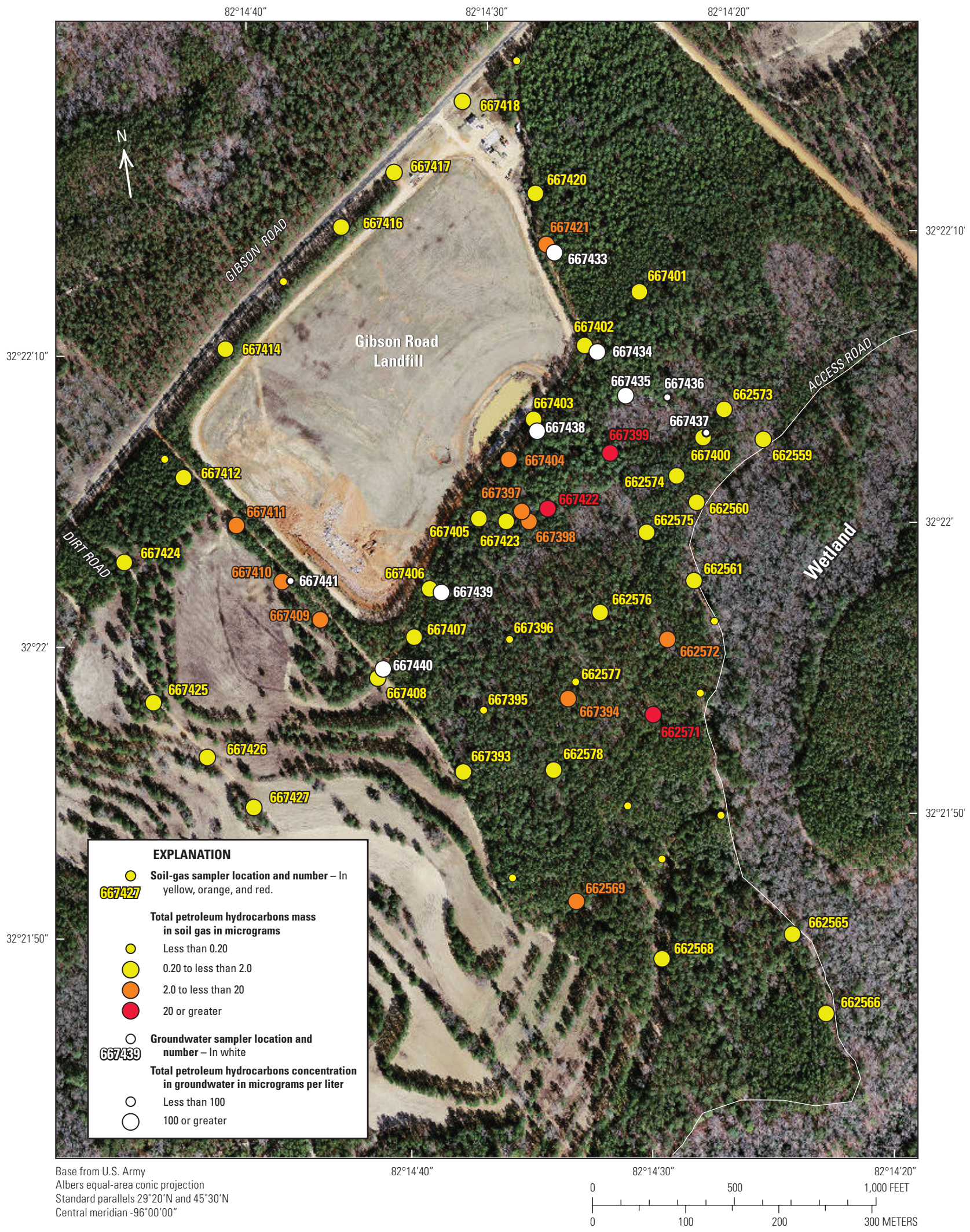

Figure 6. Locations and identification numbers for passive samplers deployed in the soil and the monitoring wells, and ranges of mass in the soil gas and concentration in groundwater for total petroleum hydrocarbons (TPH) at the Gibson Road landfill, Fort Gordon, Georgia, July 25-29, July 26-29, July 29-August 3, and August 8, 2011. Method detection level is 0.02 microgram. 


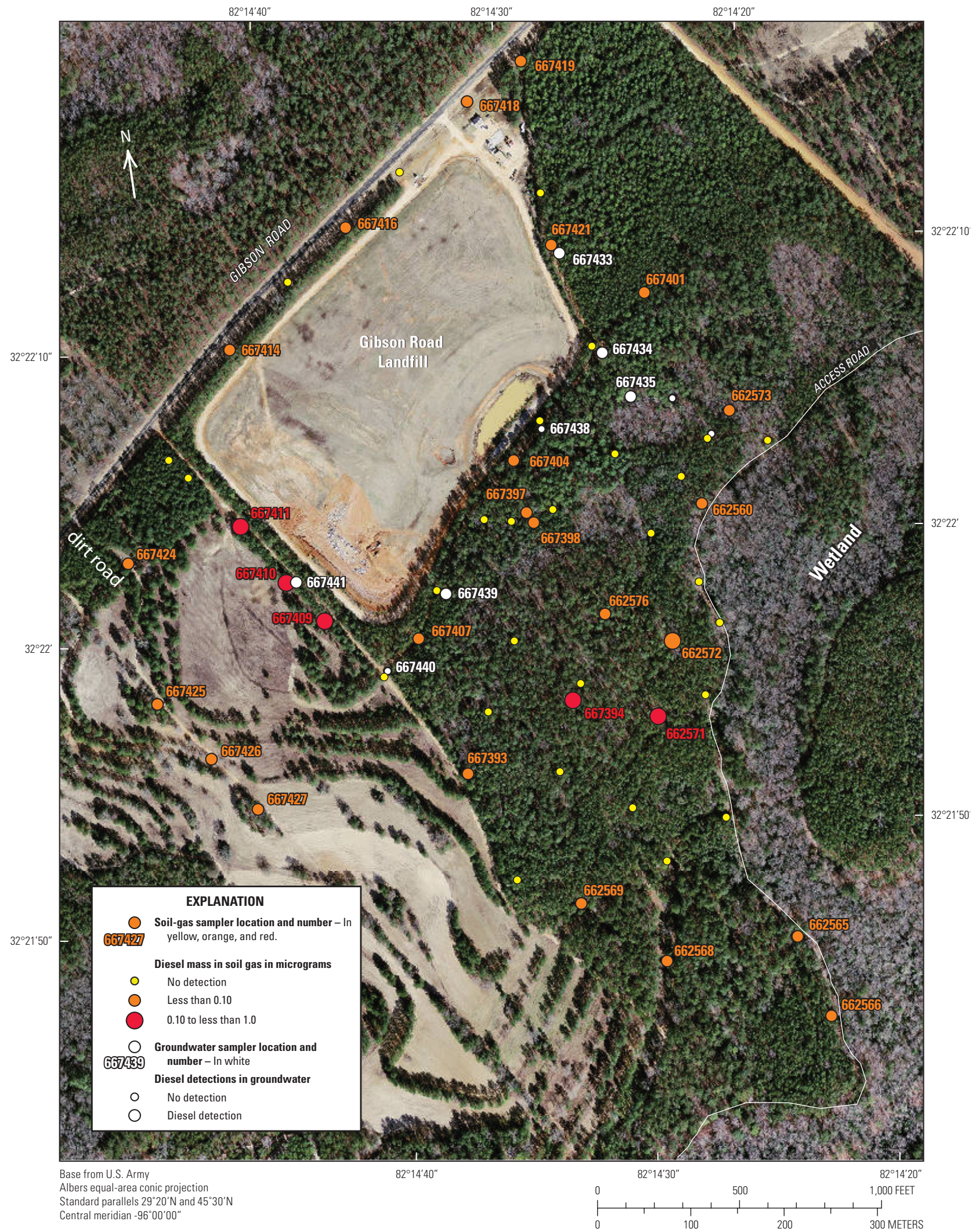

Figure 7. Locations and identification numbers for passive samplers deployed in the soil and the monitoring wells, and ranges of combined undecane, tridecane, and pentadecane $\left(\mathrm{C}_{11^{\prime}} \mathrm{C}_{13}\right.$, and $\left.\mathrm{C}_{15}\right)$ as diesel mass in soil gas, and as diesel concentration in groundwater at the Gibson Road landfill, Fort Gordon, Georgia, July 25-29, July 26-29, July 29-August 3, and August 8, 2011. Method detection level is 0.02 microgram. 


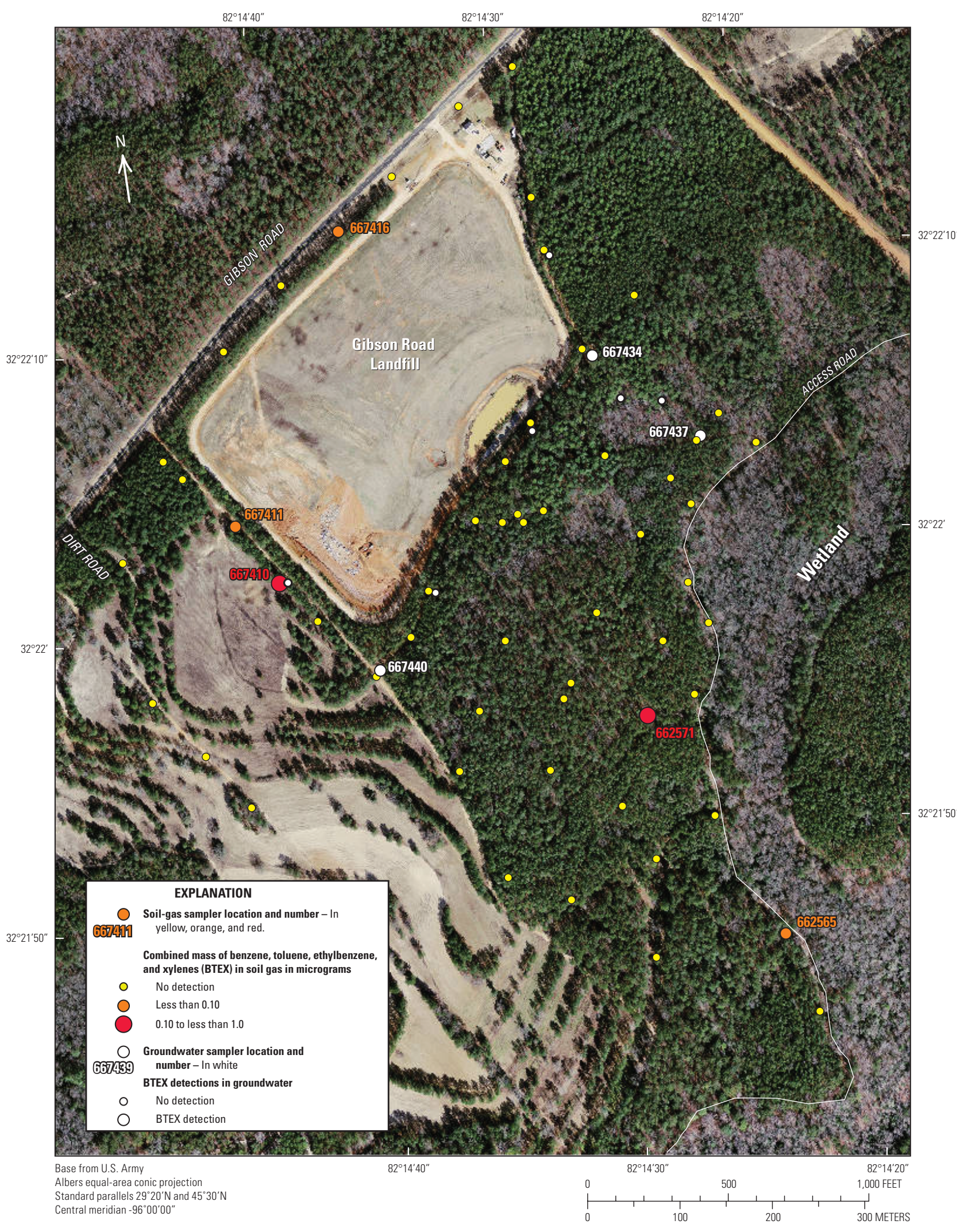

Figure 8. Locations and identification numbers for passive samplers deployed in the soil and monitoring wells, and ranges for combined benzene, toluene, ethylbenzene, and xylene as BTEX mass in the soil gas, and as BTEX concentration in groundwater at the Gibson Road landfill, Fort Gordon, Georgia, July 28-29, July 29-August 3, and August 8, 2011. 


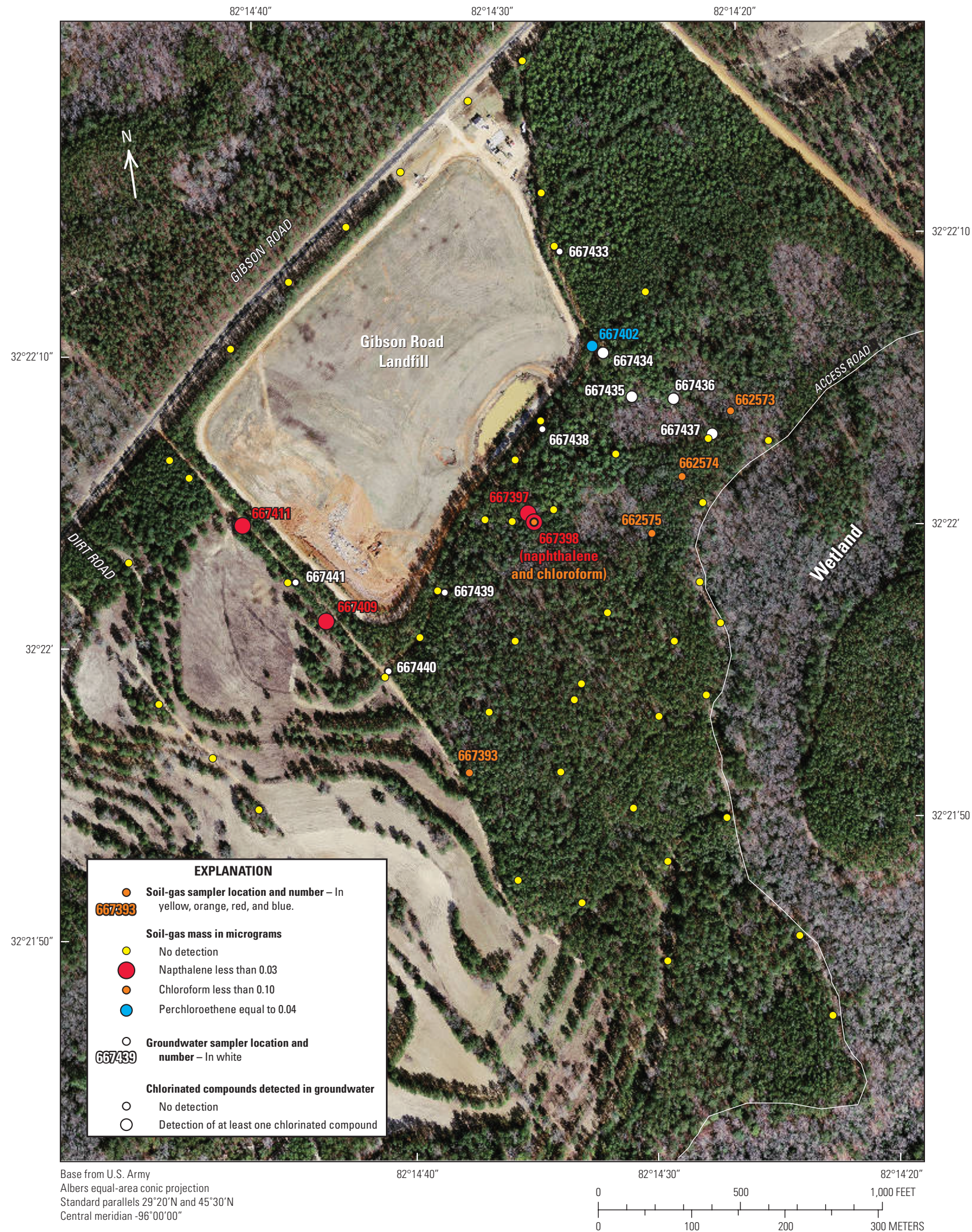

Figure 9. Locations and identification numbers for passive samplers deployed in the soil and the monitoring wells, and ranges for naphthalene, chloroform and perchloroethene as masses in the soil gas, and concentrations of chlorinated compounds in groundwater at the Gibson Road landfill, Fort Gordon, Georgia, July 28-29, July 29-August 3, and August 8, 2011. 
Six samplers had detections of chlorinated compounds and all six were located southeast (downgradient) of the landfill (fig. 9; table 2). Perchloroethene (PCE) was detected at $0.04 \mu \mathrm{g}$ in sampler 667402 at the eastern corner of the landfill (table 2). The other chlorinated compound detected in the study area was chloroform. All five chloroform detections ranged from 0.05 to $0.08 \mu \mathrm{g}$. Three samplers $(662573,662574$, and 662575) had detections of chloroform near the wetland and were downgradient from the PCE detection in sampler 667402. Chloroform also was detected in sampler 667398 with a naphthalene detection in the gully and in sampler 667393 to the southeast of the landfill.

\section{Groundwater Assessment}

Passive samplers in the groundwater assessment were deployed and recovered on August 8, 2011, in nine monitoring wells along the southwestern, southeastern, and northeastern sides from the landfill and downgradient from the eastern corner of the landfill (fig. 2). TPH was detected in all samplers in the groundwater assessment at concentrations exceeding the MDL of $8.3 \mu \mathrm{g} / \mathrm{L}$ (table 3 ). Six of the nine TPH concentrations were greater than $100 \mu \mathrm{g} / \mathrm{L}$, including concentrations in samplers $667434,667438,667439$, and 667440 along the southeastern side of the landfill, sampler 667433 on the northeastern side of the landfill, and sampler 667435 downgradient from the eastern corner of the landfill (fig. 6). The TPH concentrations less than $100 \mu \mathrm{g} / \mathrm{L}$ were in sampler 667441 on the southwestern side of the landfill and downgradient from the landfill in samplers 667436 and 667437 near the wetland. Soil-gas sampling sites located next to seven of the nine groundwater TPH detections had TPH mass greater than $0.20 \mu \mathrm{g}$.

Samplers were deployed in four wells roughly aligned between the eastern corner of the landfill and the wetland (fig. 6). The TPH concentrations declined from a concentration of $320 \mu \mathrm{g} / \mathrm{L}$ in upgradient sampler 667434 near the landfill to concentrations of $120 \mu \mathrm{g} / \mathrm{L}$ in sampler $667435,56.20 \mu \mathrm{g} / \mathrm{L}$ in sampler 667436 , and finally to a concentration of $18 \mu \mathrm{g} / \mathrm{L}$ in downgradient sampler 667437 nearest the wetland. TPH in the soil-gas samplers ranged from 0.18 to $0.88 \mu \mathrm{g} / \mathrm{L}$ in the area of these four monitoring wells with no recognizable pattern of downgradient decline in mass.

Five of the samplers had detections of one or more diesel compounds but the individual diesel compounds were reported as having concentrations below the MDL or were nondetectable (table 3 ). The combined diesel concentration for each of these five samplers was $0.00 \mu \mathrm{g} / \mathrm{L}$. Diesel was detected in sampler 667433 on the northeastern side of the landfill, samplers 667434 and 667435 near the eastern corner of the landfill, sampler 667439 on the southeastern side of the landfill, and sampler 667441 on the southwestern side of the landfill (fig. 7). The diesel detections located on the northeastern and southwestern sides of the landfill were the only two groundwater detections associated with detectable diesel mass in adjacent samplers in the soil-gas assessment.

Benzene was detected in three samplers and was the only BTEX compound detected in the groundwater assessment (table 3). The concentrations of benzene and, therefore, BTEX were $6.1 \mu \mathrm{g} / \mathrm{L}$ in sampler 667434 near the eastern corner of the landfill, $27 \mu \mathrm{g} / \mathrm{L}$ in sampler 667437 at a downgradient location near the wetland, and $37 \mu \mathrm{g} / \mathrm{L}$ in sampler 667440 at the southern corner of the landfill (fig. 8). These three concentrations exceed the National Primary Drinking Water Standard of $5.0 \mu \mathrm{g} / \mathrm{L}$ set for benzene by the USEPA (U.S. Environmental Protection Agency, 2009). Benzene and other BTEX compounds were not detected at any of the samplers in the soil-gas assessment deployed at the locations of the three groundwater samplers with BTEX.

All of the detections of nonfuel-related compounds in the groundwater assessment were in the four wells that are aligned between the eastern corner of the landfill and the wetland (fig. 9; table 3). Sampler 667434 deployed in the well nearest the eastern corner of the landfill is closest to the landfill, relative to the other three wells, and had the greatest number of detected compounds. Sampler 667434 had the only detections of the two trimethylbenzene compounds, naphthalene, 2-methyl naphthalene, and 1,4-dichlorobenzene (table 3). Chlorinated compounds were detected in samplers deployed in these four wells, but the two upgradient samplers (667434 and 667435) had the greatest number of chlorinated compounds with five compounds each, compared to four compounds in sampler 667436 and one compound in sampler 667437. The chlorinated compound with the highest concentration in each of the four samplers was 1,1-dichloroethane which ranged in concentration from $1,300 \mu \mathrm{g} / \mathrm{L}$ in sampler 667435 to $42 \mu \mathrm{g} / \mathrm{L}$ in downgradient sampler 667437. Other chlorinated compounds detected in the groundwater assessment included TCE and PCE in samplers 667434, 667435, and 667436; and cis1,2-dichloroethene in samplers 667434 and 667435. Samplers 667435 and 667436 had the only detections of 1,1,1-trichloroethane and chloroform, respectively.

The only detection of a chlorinated compound in a soilgas sampler paired with a groundwater sampler was PCE in soil-gas sampler 667402 near the eastern corner of the landfill (fig. 9). Chloroform was not detected in any of the seven samplers in the soil-gas assessment paired with seven samplers in the groundwater assessment. Likewise, none of the naphthalene detections in the soil-gas assessment were located next to the naphthalene detection in sampler 667434 of the groundwater assessment. 


\section{Summary}

Soil-gas and groundwater assessments were conducted at the Gibson Road landfill in 2011 to provide screening-level environmental contamination data to supplement the data collected during previous environmental studies at the landfill. These assessments were completed in cooperation with the U.S. Department of the Army Environmental and Natural Resources Management Office of the U.S. Army Signal Center and Fort Gordon, Georgia.

A total of 56 passive samplers were deployed for the soilgas assessment in the Gibson Road landfill study area. The survey mostly identified detections of total petroleum hydrocarbons (TPH) and diesel-range compounds, but also identified the presence of toluene, perchloroethene, chloroform, and naphthalene in a few samples. TPH mass exceeded the method detection level of 0.02 microgram in all 56 samplers. There were $13 \mathrm{TPH}$ detections with masses greater than 2.0 micrograms that were in samplers located along the northeastern and southwestern sides of the landfill and southeast (downgradient) of the landfill toward the wetland. Detections in all five samplers deployed in the gully located downgradient from landfill had TPH masses greater than 0.20 microgram. TPH exceeded a mass of 20 micrograms in three samplers located between the landfill and the wetland. The largest TPH detection had a mass of 85 micrograms and was in sampler 662571, which is located downgradient from the landfill and within 250 feet of the wetland. TPH was detected in three samplers deployed along the southwestern side of the landfill and had masses that ranged from 6.6 to 13 micrograms. TPH also was detected in samplers deployed farther to the southwest of the landfill along a dirt road in the adjacent field, which had masses ranging from 0.49 to 1.7 micrograms.

Diesel was detected in 28 of the 56 samplers in the soil-gas assessment, including detections along all four sides of the landfill, downgradient from the landfill toward the wetland, in the gully, and in the field to the southwest of the landfill. All three diesel compounds - undecane, tridecane, and pentadecane - were detected, but undecane was the most common diesel compound with 23 detections. Only five detections, however, exceeded a combined diesel mass of 0.10 microgram, including masses of $0.12,0.15$ (estimated), and 0.24 microgram along the southwestern side of the landfill, and 0.27 (estimated) and 0.11 microgram in samplers southeast of the landfill near the wetland.

Toluene was detected in only five samplers in the soil-gas assessment. The detections with the largest masses were a sampler near the wetland with a mass of 0.65 microgram and a sampler on the southwestern side of the landfill with a mass of 0.85 microgram. Toluene was the only BTEX compound detected in all five samplers. The only other gasoline-related compound detected in the soil-gas assessment was octane with a mass of 0.07 microgram in sampler 667410 and a mass reported as below detction level in sampler 667405. Naphthalene, detected in two samplers in the gully and two samplers along the southwestern side of the landfill, had masses less than or equal to 0.02 microgram. Six samplers had detections of chlorinated compounds and were located southeast (downgradient) of the landfill. The only detection of perchloroethene was in sampler 667402 at the eastern corner of the landfill, which had a mass of 0.04 microgram. Five samplers had chloroform detections, which had masses ranging from 0.05 to 0.08 microgram.

Passive samplers in the groundwater assessment were deployed and recovered on August 8, 2011, in nine monitoring wells along the southwestern, southeastern, and northeastern sides of the landfill and downgradient from the eastern corner of the landfill. TPH was detected in all samplers and had concentrations greater than 100 micrograms per liter in six of the nine samplers, including samplers along the southeastern and northeastern sides of the landfill, and a sampler just downgradient from the eastern corner of the landfill. Soil-gas sampling sites are located next to seven of the nine groundwater TPH detections and had TPH masses greater than 0.20 microgram. In four wells aligned between the eastern corner of the landfill and the wetland, TPH concentrations declined from 320 micrograms per liter in an upgradient sampler near the landfill to 18 micrograms per liter in a downgradient sampler nearest the wetland.

Five of the groundwater samplers had detections of one or more diesel compounds, but the individual diesel compounds were reported as having a concentration below the MDL or as a nondetection. Benzene was detected in three groundwater samplers and was the only BTEX compound detected in the groundwater assessment. The concentrations of benzene were 6.1 micrograms per liter in sampler 667434 at the upgradient location near the eastern corner of the landfill, 27 micrograms per liter in sampler 667437 at the downgradient location near the wetland, and 37 micrograms per liter in sampler 667440 at the southern corner of the landfill.

All of the detections of nonfuel-related compounds in the groundwater assessment were in the four wells that are aligned between the eastern corner of the landfill and the wetland. Sampler 667434 deployed in the well nearest the eastern corner of the landfill had the greatest diversity of detected compounds and had the only detections of the two trimethylbenzene compounds, naphthalene, 2-methyl naphthalene, and 1,4-dichlorobenzene in the groundwater assessment. The two upgradient samplers had the greatest diversity of chlorinated compounds with five compounds each, compared to four compounds in sampler 667436 and one compound in sampler 667437. Concentrations of 1,1-dichloroethane were the highest of all detected organic compounds and ranged from 1,300 micrograms per liter in sampler 667435 to 42 micrograms per liter in downgradient sampler 667437. Other chlorinated compounds detected in the groundwater assessment included trichloroethene, perchloroethene, cis-1,2-dichloroethene, 1,1,1-trichloroethane and chloroform. 


\section{References Cited}

Atkins, J.B., Journey, C.A., and Clarke, J.S., 1996, Estimation of ground-water discharge to streams in the central Savannah River basin of Georgia and South Carolina: U.S. Geological Survey Water-Resources Investigations Report 96-4179, 36 p.

American Society for Testing and Materials, 2006, Standard guide for soil gas monitoring in the vadose zone: West Conshohocken, Pa., ASTM D5314-92, 36 p.

Faye, R.E., and Mayer, H.C., 1990, Ground-water and stream-aquifer relations in the northern Coastal Plain of Georgia and adjacent parts of Alabama and South Carolina: U.S. Geological Survey Water-Resources Investigations Report 88-4143, 83 p.

Gregory, M.B., Stamey, T.C., and Wellborn, J.B., 2001, Ecological characterization of streams, and fish-tissue analysis for mercury and lead at selected locations, Fort Gordon, Georgia, June 1999 to May 2000: U.S. Geological Survey Open-File Report 01-203, 14 p.

Guimaraes, W.B., Falls, W.F., Caldwell, A.W., Ratliff, W.H., Wellborn, J.B., and Landmeyer, J.E., 2011, Assessment of groundwater, soil-gas, and soil contamination at the Vietnam Armor Training Facility, Fort Gordon, Georgia, 2009-2010: U.S. Geological Survey Open-File Report 2011-1200, 40 p.

Hetrick, J.H., 1992, A geologic atlas of the Wrens-Augusta area: Georgia Geologic Survey Geologic Atlas no. 8, 2 pls.

International Organization for Standardization, 1990, ISO Guide 25. General requirements for the competence of calibration and testing laboratories ( $3 \mathrm{~d}$ ed.): New York, American National Standards Institute.
Priest, Sherlyn, and McSwain, K.B., 2002, Hydrogeology and water quality of the Upper Three Runs aquifer in the vicinity of the Gibson Road Landfill, Fort Gordon, Georgia, June-November 1999: U.S. Geological Survey WaterResources Investigations Report 02-4153, 22 p.

U.S. Environmental Protection Agency, 1998, Environmental Technology Verification Report Passive Soil Gas Sampler: EPA/600/R-98/095, accessed September 1, 2010, at http://www.epa.gov/nrmrl/std/etv/pubs/01_vr_gore.pdf.

U.S. Environmental Protection Agency, 2000, Environmental Technology Verification Report Groundwater Sampling Technologies: EPA/600/R-00/091, accessed September 1, 2010 at http://www.epa.gov/nrmrl/std/etv/pubs/ 01_vr_gore.pdf.

U.S. Environmental Protection Agency, 2006, The method of evaluating solid waste-Physical chemical methods ( $3 \mathrm{~d}$ ed.), final update IV of SW-846, accessed March 22, 2010, at http://www.epa.gov/fedrgstr/EPA-WASTE/2008/January/ Day-03/f25575.htm.

U.S. Environmental Protection Agency, 2009, National Primary Drinking Water Regulations: EPA 816-F-09-004, 6 p., accessed April 30, 2012, at http://www.epa.gov/ogwdw/ consumer/pdf/mcl.pdf.

Williams, L.J., 2007, Hydrogeology and potentiometric surface of the Dublin and Midville aquifer systems in Richmond County, Georgia, January 2007: U.S. Geological Survey Scientific Investigations Map 2982, 1 sheet.

W.L. Gore \& Associates, Inc., 2004, GORE ${ }^{\mathrm{TM}}$ surveys for site assessment \& monitoring, accessed February 24, 2011, at http://www.gore.com/MungoBlobs/239/659/ surveys_environmental_brochure.pdf. 
Tables 1-3 
Table 1. Gore identification numbers and location information for passive samplers deployed and recovered in the soil-gas assessment from July 25-29, July 26-29, and July 29-August 3, 2011, and groundwater assessment on August 8, 2011, at the Gibson Road landfill study area, Fort Gordon, Georgia.

$[-$, no data $]$

\begin{tabular}{|c|c|c|c|c|c|}
\hline $\begin{array}{c}\text { Gore } \\
\text { identification } \\
\text { number }\end{array}$ & $\begin{array}{l}\text { Use of } \\
\text { sampler }\end{array}$ & $\begin{array}{c}\text { Latitude, } \\
\text { decimal degrees de }\end{array}$ & $\begin{array}{l}\text { Longitude, } \\
\text { ecimal degrees }\end{array}$ & $\begin{array}{l}\text { Sampling } \\
\text { period }\end{array}$ & $\begin{array}{c}\text { Date } \\
\text { analyzed }\end{array}$ \\
\hline 662559 & Soil Gas & 33.367667 & 82.239194 & $7 / 25-7 / 29$ & $8 / 26$ \\
\hline 662560 & Soil Gas & 33.367167 & 82.240056 & $7 / 25-7 / 29$ & $8 / 25$ \\
\hline 662561 & Soil Gas & 33.366417 & 82.240222 & $7 / 25-7 / 29$ & $8 / 26$ \\
\hline 662562 & Soil Gas & 33.366000 & 82.240056 & $7 / 25-7 / 29$ & $8 / 26$ \\
\hline 662563 & Soil Gas & 33.365333 & 82.240333 & $7 / 25-7 / 29$ & $8 / 26$ \\
\hline 662564 & Soil Gas & 33.364139 & 82.240306 & $7 / 25-7 / 29$ & $8 / 26$ \\
\hline 662565 & Soil Gas & 33.362917 & 82.239667 & $7 / 25-7 / 29$ & $8 / 26$ \\
\hline 662566 & Soil Gas & 33.362111 & 82.239417 & $7 / 25-7 / 29$ & $8 / 26$ \\
\hline 662567 & Soil Gas & 33.363806 & 82.241056 & $7 / 25-7 / 29$ & $8 / 26$ \\
\hline 662568 & Soil Gas & 33.362861 & 82.241222 & $7 / 25-7 / 29$ & $8 / 25$ \\
\hline 662569 & Soil Gas & 33.363528 & 82.242111 & $7 / 25-7 / 29$ & $8 / 25$ \\
\hline 662570 & Soil Gas & 33.364361 & 82.241361 & $7 / 25-7 / 29$ & $8 / 26$ \\
\hline 662571 & Soil Gas & 33.365194 & 82.240917 & $7 / 25-7 / 29$ & $8 / 29$ \\
\hline 662572 & Soil Gas & 33.365889 & 82.240611 & $7 / 25-7 / 29$ & $8 / 25$ \\
\hline 662573 & Soil Gas & 33.368000 & 82.239583 & $7 / 25-7 / 29$ & $8 / 25$ \\
\hline 662574 & Soil Gas & 33.367444 & 82.240250 & $7 / 25-7 / 29$ & $8 / 26$ \\
\hline 662575 & Soil Gas & 33.366944 & 82.240694 & $7 / 25-7 / 29$ & $8 / 25$ \\
\hline 662576 & Soil Gas & 33.366250 & 82.241333 & $7 / 25-7 / 29$ & $8 / 26$ \\
\hline 662577 & Soil Gas & 33.365611 & 82.241750 & $7 / 25-7 / 29$ & $8 / 25$ \\
\hline 662578 & Soil Gas & 33.364806 & 82.242139 & $7 / 25-7 / 29$ & $8 / 26$ \\
\hline 662579 & Soil Gas & 33.363833 & 82.242806 & $7 / 25-7 / 29$ & $8 / 26$ \\
\hline 667393 & Soil Gas & 33.364917 & 82.243194 & $7 / 25-7 / 29$ & $8 / 27$ \\
\hline 667394 & Soil Gas & 33.365472 & 82.241861 & $7 / 25-7 / 29$ & $8 / 26$ \\
\hline 667395 & Soil Gas & 33.365472 & 82.242861 & $7 / 25-7 / 29$ & $8 / 26$ \\
\hline 667396 & Soil Gas & 33.366111 & 82.242444 & $7 / 25-7 / 29$ & $8 / 27$ \\
\hline 667397 & Soil Gas & 33.367306 & 82.242083 & $7 / 25-7 / 29$ & $8 / 26$ \\
\hline 667398 & Soil Gas & 33.367222 & 82.242028 & $7 / 25-7 / 29$ & $8 / 26$ \\
\hline 667399 & Soil Gas & 33.367750 & 82.240972 & $7 / 25-7 / 29$ & $8 / 29$ \\
\hline 667400 & Soil Gas & 33.367778 & 82.239861 & $7 / 25-7 / 29$ & $8 / 27$ \\
\hline 667401 & Soil Gas & 33.369250 & 82.240361 & $7 / 25-7 / 29$ & $8 / 26$ \\
\hline 667402 & Soil Gas & 33.368806 & 82.241056 & $7 / 25-7 / 29$ & $8 / 26$ \\
\hline 667403 & Soil Gas & 33.368167 & 82.241778 & $7 / 25-7 / 29$ & $8 / 25$ \\
\hline 667404 & Soil Gas & 33.367833 & 82.242139 & $7 / 25-7 / 29$ & $8 / 26$ \\
\hline 667405 & Soil Gas & 33.367306 & 82.242583 & $7 / 25-7 / 29$ & $8 / 26$ \\
\hline 667406 & Soil Gas & 33.366694 & 82.243250 & $7 / 25-7 / 29$ & $8 / 25$ \\
\hline 667407 & Soil Gas & 33.366278 & 82.243528 & $7 / 25-7 / 29$ & $8 / 26$ \\
\hline 667408 & Soil Gas & 33.365944 & 82.244000 & $7 / 25-7 / 29$ & $8 / 26$ \\
\hline 667409 & Soil Gas & 33.366556 & 82.244583 & $7 / 25-7 / 29$ & $8 / 26$ \\
\hline
\end{tabular}


Table 1. Gore identification numbers and location information for passive samplers deployed and recovered in the soil-gas assessment from July 25-29, July 26-29, and July 29-August 3, 2011, and groundwater assessment on August 8, 2011, at the Gibson Road landfill study area, Fort Gordon, Georgia. —Continued

[-, no data]

\begin{tabular}{|c|c|c|c|c|c|}
\hline \multirow{2}{*}{$\begin{array}{c}\text { Gore } \\
\text { identification } \\
\text { number }\end{array}$} & \multirow{2}{*}{$\begin{array}{c}\text { Use of } \\
\text { sampler }\end{array}$} & \multicolumn{2}{|c|}{$\begin{array}{c}\text { Latitude, } \\
\text { Longitude, } \\
\text { decimal degrees decimal degrees }\end{array}$} & \multirow{2}{*}{$\begin{array}{c}\begin{array}{c}\text { Sampling } \\
\text { period }\end{array} \\
7 / 25-7 / 29\end{array}$} & \multirow{2}{*}{$\begin{array}{c}\begin{array}{c}\text { Date } \\
\text { analyzed }\end{array} \\
8 / 26\end{array}$} \\
\hline & & 33.366972 & 82.244917 & & \\
\hline 667411 & Soil Gas & 33.367583 & 82.245389 & $7 / 25-7 / 29$ & $8 / 26$ \\
\hline 667412 & Soil Gas & 33.368111 & 82.245917 & $7 / 25-7 / 29$ & $8 / 25$ \\
\hline 667413 & Soil Gas & 33.368306 & 82.246111 & $7 / 25-7 / 29$ & $8 / 25$ \\
\hline 667414 & Soil Gas & 33.369278 & 82.245222 & $7 / 25-7 / 29$ & $8 / 26$ \\
\hline 667415 & Soil Gas & 33.369833 & 82.244444 & $7 / 25-7 / 29$ & $8 / 25$ \\
\hline 667416 & Soil Gas & 33.370278 & 82.243694 & $7 / 25-7 / 29$ & $8 / 26$ \\
\hline 667417 & Soil Gas & 33.370722 & 82.242972 & $7 / 25-7 / 29$ & $8 / 26$ \\
\hline 667418 & Soil Gas & 33.371306 & 82.242083 & $7 / 25-7 / 29$ & $8 / 26$ \\
\hline 667419 & Soil Gas & 33.371611 & 82.241389 & $7 / 25-7 / 29$ & $8 / 25$ \\
\hline 667420 & Soil Gas & 33.370333 & 82.241389 & $7 / 25-7 / 29$ & $8 / 26$ \\
\hline 667421 & Soil Gas & 33.369806 & 82.241333 & $7 / 26-7 / 29$ & $8 / 26$ \\
\hline 667422 & Soil Gas & 33.367306 & 82.241778 & $7 / 26-7 / 29$ & $8 / 29$ \\
\hline 667423 & Soil Gas & 33.367250 & 82.242278 & $7 / 26-7 / 29$ & $8 / 26$ \\
\hline 667424 & Soil Gas & 33.367389 & 82.246750 & $7 / 29-8 / 3$ & $8 / 27$ \\
\hline 667425 & Soil Gas & 33.366000 & 82.246639 & $7 / 29-8 / 3$ & $8 / 26$ \\
\hline 667426 & Soil Gas & 33.365417 & 82.246111 & $7 / 29-8 / 3$ & $8 / 26$ \\
\hline 667427 & Soil Gas & 33.364861 & 82.245667 & $7 / 29-8 / 3$ & $8 / 26$ \\
\hline 667428 & Trip blank & - & - & - & $8 / 26$ \\
\hline 667429 & Trip blank & - & - & - & $8 / 26$ \\
\hline 667430 & Trip blank & - & - & - & $8 / 26$ \\
\hline 667431 & Trip blank & - & - & - & $8 / 26$ \\
\hline 667432 & Trip blank & - & - & - & $8 / 26$ \\
\hline 667433 & Well water & 33.369750 & 82.241278 & $8 / 8$ & $8 / 27$ \\
\hline 667434 & Well water & 33.368750 & 82.240972 & $8 / 8$ & $8 / 27$ \\
\hline 667435 & Well water & 33.368278 & 82.240694 & $8 / 8$ & $8 / 27$ \\
\hline 667436 & Well water & 33.368194 & 82.240222 & $8 / 8$ & $8 / 27$ \\
\hline 667437 & Well water & 33.367806 & 82.239833 & $8 / 8$ & $8 / 27$ \\
\hline 667438 & Well water & 33.368083 & 82.241778 & $8 / 8$ & $8 / 27$ \\
\hline 667439 & Well water & 33.366667 & 82.243167 & $8 / 8$ & $8 / 27$ \\
\hline 667440 & Well water & 33.366000 & 82.243944 & $8 / 8$ & $8 / 27$ \\
\hline 667441 & Well water & 33.350306 & 82.244861 & $8 / 8$ & $8 / 29$ \\
\hline 667442 & Trip blank & - & - & - & $8 / 27$ \\
\hline 667443 & Trip blank & - & - & - & $8 / 27$ \\
\hline- & Method blank & - & - & - & $8 / 25$ \\
\hline - & Method blank & - & - & - & $8 / 26$ \\
\hline- & Method blank & - & - & - & $8 / 27$ \\
\hline- & Method blank & - & - & - & $8 / 29$ \\
\hline
\end{tabular}


Table 2. Masses of volatile and semivolatile organic compounds and polycyclic aromatic hydrocarbons detected in passive samplers deployed and recovered during the soil-gas assessment in the Gibson Road landfill study area, Fort Gordon, Georgia, July 25-29, July 26-29, and July 29-August 3, 2011.

[Raw data provided by W.L. Gore \& Associates, Inc. rounded to two significant figures; MDL, method detection level; $\mu \mathrm{g}$, micrograms; Sampler 662559, example of unique identification number assigned by W.L. Gore \& Associates to passive sampler; N/A, not applicable; nd, not detected; E, the reported value for a combined mass should be considered estimated if the masses of any of the individual compounds used to calculate the combined mass were reported as below detection level; bdl, below detection level; a value of 0.00 (reporting format of W.L. Gore \& Associates, Inc.) is reported for a combined mass if the individual compounds included in the combined mass were not detected above method detection levels and at least one of the individual compounds was reported as below detection level]

\begin{tabular}{|c|c|c|c|c|c|c|c|c|c|c|c|c|}
\hline \multirow{2}{*}{$\begin{array}{l}\text { Organic } \\
\text { compounds }\end{array}$} & \multirow{2}{*}{$\begin{array}{l}\text { MDL } \\
(\mu g)\end{array}$} & \multicolumn{11}{|c|}{ Sampler } \\
\hline & & 662559 & 662560 & 662561 & 662562 & 662563 & 662564 & 662565 & 662566 & 662567 & 662568 & 662569 \\
\hline Total petroleum hydrocarbon (TPH) & 0.02 & 0.27 & 0.73 & 0.22 & 0.13 & 0.09 & 0.17 & 1.80 & 1.50 & 0.12 & 0.25 & 5.60 \\
\hline BTEX (gasoline) ${ }^{1}$ & N/A & nd & nd & nd & nd & nd & nd & 0.03 & nd & nd & nd & nd \\
\hline Benzene & 0.01 & nd & nd & nd & nd & nd & nd & nd & nd & nd & nd & nd \\
\hline Toluene & 0.01 & nd & nd & nd & nd & nd & nd & 0.03 & nd & nd & nd & nd \\
\hline Ethylbenzene & 0.02 & nd & nd & nd & nd & nd & nd & nd & nd & nd & nd & nd \\
\hline meta- and para-Xylene & 0.02 & nd & nd & nd & nd & nd & nd & nd & nd & nd & nd & nd \\
\hline ortho-Xylene, & 0.01 & nd & nd & nd & nd & nd & nd & nd & nd & nd & nd & nd \\
\hline $\mathrm{C}_{11}, \mathrm{C}_{13}$, and $\mathrm{C}_{15}(\text { diesel })^{1}$ & N/A & nd & 0.02 & nd & nd & nd & nd & E0.02 & E0.05 & nd & 0.00 & 0.00 \\
\hline Undecane & 0.01 & nd & 0.02 & nd & nd & nd & nd & 0.01 & 0.05 & nd & nd & nd \\
\hline Tridecane & 0.01 & nd & nd & nd & nd & nd & nd & 0.01 & bdl & nd & bdl & bdl \\
\hline Pentadecane & 0.01 & nd & nd & nd & nd & nd & nd & bdl & bdl & nd & nd & nd \\
\hline Octane & 0.02 & nd & nd & nd & nd & nd & nd & nd & nd & nd & nd & nd \\
\hline Methyl tert-butyl ether & 0.03 & nd & nd & nd & nd & nd & nd & nd & nd & nd & nd & nd \\
\hline Trimethylbenzene ${ }^{1}$ & N/A & nd & nd & nd & nd & nd & nd & nd & nd & nd & nd & nd \\
\hline 1,2,4-Trimethylbenzene & 0.01 & nd & nd & nd & nd & nd & nd & nd & nd & nd & nd & nd \\
\hline 1,3,5-Trimethylbenzene & 0.02 & nd & nd & nd & nd & nd & nd & nd & nd & nd & nd & nd \\
\hline 1,2-Dichlorobenzene & 0.01 & nd & nd & nd & nd & nd & nd & nd & nd & nd & nd & nd \\
\hline 1,3-Dichlorobenzene & 0.01 & nd & nd & nd & nd & nd & nd & nd & nd & nd & nd & nd \\
\hline 1,4-Dichlorobenzene & 0.01 & nd & nd & nd & nd & nd & nd & nd & nd & nd & nd & nd \\
\hline Chlorobenzene & 0.03 & nd & nd & nd & nd & nd & nd & nd & nd & nd & nd & nd \\
\hline Chloroform & 0.01 & nd & nd & nd & nd & nd & nd & nd & nd & nd & nd & nd \\
\hline cis- and trans-1,2-Dichloroethene $^{1}$ & $\mathrm{~N} / \mathrm{A}$ & nd & nd & nd & nd & nd & nd & nd & nd & nd & nd & nd \\
\hline trans-1,2-Dichloroethene & 0.05 & nd & nd & nd & nd & nd & nd & nd & nd & nd & nd & nd \\
\hline cis-1,2-Dichloroethene & 0.02 & nd & nd & nd & nd & nd & nd & nd & nd & nd & nd & nd \\
\hline Trichloroethene & 0.02 & nd & nd & nd & nd & nd & nd & nd & nd & nd & nd & nd \\
\hline Perchloroethene & 0.02 & nd & nd & nd & nd & nd & nd & nd & nd & nd & nd & nd \\
\hline 1,1-Dichloroethane & 0.02 & nd & nd & nd & nd & nd & nd & nd & nd & nd & nd & nd \\
\hline 1,2-Dichloroethane & 0.01 & nd & nd & nd & nd & nd & nd & nd & nd & nd & nd & nd \\
\hline 1,1,1-Trichloroethane & 0.01 & nd & nd & nd & nd & nd & nd & nd & nd & nd & nd & nd \\
\hline 1,1,2-Trichloroethane & 0.02 & nd & nd & nd & nd & nd & nd & nd & nd & nd & nd & nd \\
\hline 1,1,1,2-Tetrachloroethane & 0.02 & nd & nd & nd & nd & nd & nd & nd & nd & nd & nd & nd \\
\hline 1,1,2,2-Tetrachloroethane & 0.01 & nd & nd & nd & nd & nd & nd & nd & nd & nd & nd & nd \\
\hline Carbon tetrachloride & 0.03 & nd & nd & nd & nd & nd & nd & nd & nd & nd & nd & nd \\
\hline Naphthalene and 2-Methyl naphthalene ${ }^{1}$ & N/A & nd & nd & nd & nd & nd & nd & nd & nd & nd & nd & nd \\
\hline Naphthalene & 0.01 & nd & nd & nd & nd & nd & nd & nd & nd & nd & nd & nd \\
\hline 2-Methyl naphthalene & 0.01 & nd & nd & nd & nd & nd & nd & nd & nd & nd & nd & nd \\
\hline
\end{tabular}


Table 2. Masses of volatile and semivolatile organic compounds and polycyclic aromatic hydrocarbons detected in passive samplers deployed and recovered during the soil-gas assessment in the Gibson Road landfill study area, Fort Gordon, Georgia, July 25-29, July 26-29, and July 29-August 3, 2011. - Continued

[Raw data provided by W.L. Gore \& Associates, Inc. rounded to two significant figures; MDL, method detection level; $\mu$ g, micrograms; Sampler 662559, example of unique identification number assigned by W.L. Gore \& Associates to passive sampler; N/A, not applicable; nd, not detected; E, the reported value for a combined mass should be considered estimated if the masses of any of the individual compounds used to calculate the combined mass were reported as below detection level; bdl, below detection level; a value of 0.00 (reporting format of W.L. Gore \& Associates, Inc.) is reported for a combined mass if the individual compounds included in the combined mass were not detected above method detection levels and at least one of the individual compounds was reported as below detection level]

\begin{tabular}{|c|c|c|c|c|c|c|c|c|c|c|c|c|}
\hline \multirow{2}{*}{$\begin{array}{c}\text { Organic } \\
\text { compounds }\end{array}$} & \multirow{2}{*}{$\begin{array}{l}\text { MDL } \\
(\mu \mathrm{g})\end{array}$} & \multicolumn{11}{|c|}{ Sampler } \\
\hline & & 662570 & 662571 & 662572 & 662573 & 662574 & 662575 & 662576 & 662577 & 662578 & 662579 & 667393 \\
\hline Total petroleum hydrocarbon (TPH) & 0.02 & 0.07 & 85.00 & 3.30 & 0.88 & 0.34 & 0.43 & 1.3 & 0.11 & 1.4 & 0.14 & 0.23 \\
\hline BTEX (gasoline) ${ }^{1}$ & N/A & nd & 0.65 & nd & nd & nd & nd & nd & nd & nd & nd & nd \\
\hline Benzene & 0.01 & nd & nd & nd & nd & nd & nd & nd & nd & nd & nd & nd \\
\hline Toluene & 0.01 & nd & 0.65 & nd & nd & nd & nd & nd & nd & nd & nd & nd \\
\hline Ethylbenzene & 0.02 & nd & nd & nd & nd & nd & nd & nd & nd & nd & nd & nd \\
\hline meta- and para-Xylene & 0.02 & nd & nd & nd & nd & nd & nd & nd & nd & nd & nd & nd \\
\hline ortho-Xylene, & 0.01 & nd & nd & nd & nd & nd & nd & nd & nd & nd & nd & nd \\
\hline $\mathrm{C}_{11}, \mathrm{C}_{13}$, and $\mathrm{C}_{15}(\text { diesel })^{1}$ & N/A & nd & E0.27 & 0.00 & 0.00 & nd & nd & 0.00 & nd & nd & nd & 0.02 \\
\hline Undecane & 0.01 & nd & 0.27 & bdl & nd & nd & nd & nd & nd & nd & nd & 0.02 \\
\hline Tridecane & 0.01 & nd & nd & bdl & nd & nd & nd & nd & nd & nd & nd & nd \\
\hline Pentadecane & 0.01 & nd & nd & nd & bdl & nd & nd & bdl & nd & nd & nd & nd \\
\hline Octane & 0.02 & nd & nd & nd & nd & nd & nd & nd & nd & nd & nd & nd \\
\hline Methyl tert-butyl ether & 0.03 & nd & nd & nd & nd & nd & nd & nd & nd & nd & nd & nd \\
\hline Trimethylbenzene $^{1}$ & N/A & nd & nd & nd & nd & nd & nd & nd & nd & nd & nd & nd \\
\hline $1,2,4$-Trimethylbenzene & 0.01 & nd & nd & nd & nd & nd & nd & nd & nd & nd & nd & nd \\
\hline 1,3,5-Trimethylbenzene & 0.02 & nd & nd & nd & nd & nd & nd & nd & nd & nd & nd & nd \\
\hline 1,2-Dichlorobenzene & 0.01 & nd & nd & nd & nd & nd & nd & nd & nd & nd & nd & nd \\
\hline 1,3-Dichlorobenzene & 0.01 & nd & nd & nd & nd & nd & nd & nd & nd & nd & nd & nd \\
\hline 1,4-Dichlorobenzene & 0.01 & nd & nd & nd & nd & nd & nd & nd & nd & nd & nd & nd \\
\hline Chlorobenzene & 0.03 & nd & nd & nd & nd & nd & nd & nd & nd & nd & nd & nd \\
\hline Chloroform & 0.01 & nd & nd & nd & 0.06 & 0.08 & 0.07 & nd & nd & nd & nd & 0.05 \\
\hline cis- and trans-1,2-Dichloroethene $^{1}$ & N/A & nd & nd & nd & nd & nd & nd & nd & nd & nd & nd & nd \\
\hline trans-1,2-Dichloroethene & 0.05 & nd & nd & nd & nd & nd & nd & nd & nd & nd & nd & nd \\
\hline cis-1,2-Dichloroethene & 0.02 & nd & nd & nd & nd & nd & nd & nd & nd & nd & nd & nd \\
\hline Trichloroethene & 0.02 & nd & nd & nd & nd & nd & nd & nd & nd & nd & nd & nd \\
\hline Perchloroethene & 0.02 & nd & nd & nd & nd & nd & nd & nd & nd & nd & nd & nd \\
\hline 1,1-Dichloroethane & 0.02 & nd & nd & nd & nd & nd & nd & nd & nd & nd & nd & nd \\
\hline 1,2-Dichloroethane & 0.01 & nd & nd & nd & nd & nd & nd & nd & nd & nd & nd & nd \\
\hline 1,1,1-Trichloroethane & 0.01 & nd & nd & nd & nd & nd & nd & nd & nd & nd & nd & nd \\
\hline 1,1,2-Trichloroethane & 0.02 & nd & nd & nd & nd & nd & nd & nd & nd & nd & nd & nd \\
\hline 1,1,1,2-Tetrachloroethane & 0.02 & nd & nd & nd & nd & nd & nd & nd & nd & nd & nd & nd \\
\hline 1,1,2,2-Tetrachloroethane & 0.01 & nd & nd & nd & nd & nd & nd & nd & nd & nd & nd & nd \\
\hline Carbon tetrachloride & 0.03 & nd & nd & nd & nd & nd & nd & nd & nd & nd & nd & nd \\
\hline Naphthalene and 2-Methyl naphthalene ${ }^{1}$ & $\mathrm{~N} / \mathrm{A}$ & nd & nd & nd & nd & nd & nd & nd & nd & nd & nd & nd \\
\hline Naphthalene & 0.01 & nd & nd & nd & nd & nd & nd & nd & nd & nd & nd & nd \\
\hline 2-Methyl naphthalene & 0.01 & nd & nd & nd & nd & nd & nd & nd & nd & nd & nd & nd \\
\hline
\end{tabular}


Table 2. Masses of volatile and semivolatile organic compounds and polycyclic aromatic hydrocarbons detected in passive samplers deployed and recovered during the soil-gas assessment in the Gibson Road landfill study area, Fort Gordon, Georgia, July 25-29, July 26-29, and July 29-August 3, 2011. - Continued

[Raw data provided by W.L. Gore \& Associates, Inc. rounded to two significant figures; MDL, method detection level; $\mu \mathrm{g}$, micrograms; Sampler 662559, example of unique identification number assigned by W.L. Gore \& Associates to passive sampler; N/A, not applicable; nd, not detected; E, the reported value for a combined mass should be considered estimated if the masses of any of the individual compounds used to calculate the combined mass were reported as below detection level; bdl, below detection level; a value of 0.00 (reporting format of W.L. Gore \& Associates, Inc.) is reported for a combined mass if the individual compounds included in the combined mass were not detected above method detection levels and at least one of the individual compounds was reported as below detection level]

\begin{tabular}{|c|c|c|c|c|c|c|c|c|c|c|c|c|}
\hline \multirow{2}{*}{$\begin{array}{c}\text { Organic } \\
\text { compounds }\end{array}$} & \multirow{2}{*}{$\begin{array}{c}\text { MDL } \\
(\mu \mathrm{g})\end{array}$} & \multicolumn{11}{|c|}{ Sampler } \\
\hline & & 667394 & 667395 & 667396 & 667397 & 667398 & 667399 & 667400 & 667401 & 667402 & 667403 & 667404 \\
\hline Total petroleum hydrocarbon (TPH) & 0.02 & 2.8 & 0.18 & 0.09 & 5.7 & 8.8 & 28 & 0.18 & 1.2 & 0.62 & 0.26 & 2.3 \\
\hline BTEX (gasoline) ${ }^{1}$ & N/A & nd & nd & nd & nd & nd & nd & nd & nd & nd & nd & nd \\
\hline Benzene & 0.01 & nd & nd & nd & nd & nd & nd & nd & nd & nd & nd & nd \\
\hline Toluene & 0.01 & nd & nd & nd & nd & nd & nd & nd & nd & nd & nd & nd \\
\hline Ethylbenzene & 0.02 & nd & nd & nd & nd & nd & nd & nd & nd & nd & nd & nd \\
\hline meta- and para-Xylene & 0.02 & nd & nd & nd & nd & nd & nd & nd & nd & nd & nd & nd \\
\hline ortho-Xylene, & 0.01 & nd & nd & nd & nd & nd & nd & nd & nd & nd & nd & nd \\
\hline $\mathrm{C}_{11}, \mathrm{C}_{13}$, and $\mathrm{C}_{15}(\text { diesel })^{1}$ & N/A & 0.11 & nd & nd & E0.03 & E0.01 & nd & nd & 0.04 & nd & nd & E0.06 \\
\hline Undecane & 0.01 & 0.10 & nd & nd & 0.03 & 0.01 & nd & nd & 0.04 & nd & nd & 0.06 \\
\hline Tridecane & 0.01 & 0.01 & nd & nd & bdl & bdl & nd & nd & nd & nd & nd & bdl \\
\hline Pentadecane & 0.01 & nd & nd & nd & nd & nd & nd & nd & nd & nd & nd & nd \\
\hline Octane & 0.02 & nd & nd & nd & nd & nd & nd & nd & nd & nd & nd & nd \\
\hline Methyl tert-butyl ether & 0.03 & nd & nd & nd & nd & nd & nd & nd & nd & nd & nd & nd \\
\hline Trimethylbenzene $^{1}$ & N/A & nd & nd & nd & nd & nd & nd & nd & nd & nd & nd & nd \\
\hline 1,2,4-Trimethylbenzene & 0.01 & nd & nd & nd & nd & nd & nd & nd & nd & nd & nd & nd \\
\hline 1,3,5-Trimethylbenzene & 0.02 & nd & nd & nd & nd & nd & nd & nd & nd & nd & nd & nd \\
\hline 1,2-Dichlorobenzene & 0.01 & nd & nd & nd & nd & nd & nd & nd & nd & nd & nd & nd \\
\hline 1,3-Dichlorobenzene & 0.01 & nd & nd & nd & nd & nd & nd & nd & nd & nd & nd & nd \\
\hline 1,4-Dichlorobenzene & 0.01 & nd & nd & nd & nd & nd & nd & nd & nd & nd & nd & nd \\
\hline Chlorobenzene & 0.03 & nd & nd & nd & nd & nd & nd & nd & nd & nd & nd & nd \\
\hline Chloroform & 0.01 & nd & nd & nd & nd & 0.05 & nd & nd & nd & nd & nd & nd \\
\hline cis- and trans-1,2-Dichloroethene $^{1}$ & $\mathrm{~N} / \mathrm{A}$ & nd & nd & nd & nd & nd & nd & nd & nd & nd & nd & nd \\
\hline trans-1,2-Dichloroethene & 0.05 & nd & nd & nd & nd & nd & nd & nd & nd & nd & nd & nd \\
\hline cis-1,2-Dichloroethene & 0.02 & nd & nd & nd & nd & nd & nd & nd & nd & nd & nd & nd \\
\hline Trichloroethene & 0.02 & nd & nd & nd & nd & nd & nd & nd & nd & nd & nd & nd \\
\hline Perchloroethene & 0.02 & nd & nd & nd & nd & nd & nd & nd & nd & 0.04 & nd & nd \\
\hline 1,1-Dichloroethane & 0.02 & nd & nd & nd & nd & nd & nd & nd & nd & nd & nd & nd \\
\hline 1,2-Dichloroethane & 0.01 & nd & nd & nd & nd & nd & nd & nd & nd & nd & nd & nd \\
\hline 1,1,1-Trichloroethane & 0.01 & nd & nd & nd & nd & nd & nd & nd & nd & nd & nd & nd \\
\hline 1,1,2-Trichloroethane & 0.02 & nd & nd & nd & nd & nd & nd & nd & nd & nd & nd & nd \\
\hline 1,1,1,2-Tetrachloroethane & 0.02 & nd & nd & nd & nd & nd & nd & nd & nd & nd & nd & nd \\
\hline 1,1,2,2-Tetrachloroethane & 0.01 & nd & nd & nd & nd & nd & nd & nd & nd & nd & nd & nd \\
\hline Carbon tetrachloride & 0.03 & nd & nd & nd & nd & nd & nd & nd & nd & nd & nd & nd \\
\hline Naphthalene and 2-Methyl naphthalene ${ }^{1}$ & N/A & nd & nd & nd & 0.01 & 0.02 & nd & nd & nd & nd & nd & nd \\
\hline Naphthalene & 0.01 & nd & nd & nd & 0.01 & 0.02 & nd & nd & nd & nd & nd & nd \\
\hline 2-Methyl naphthalene & 0.01 & nd & nd & nd & nd & nd & nd & nd & nd & nd & nd & nd \\
\hline
\end{tabular}


Table 2. Masses of volatile and semivolatile organic compounds and polycyclic aromatic hydrocarbons detected in passive samplers deployed and recovered during the soil-gas assessment in the Gibson Road landfill study area, Fort Gordon, Georgia, July 25-29, July 26-29, and July 29-August 3, 2011. - Continued

[Raw data provided by W.L. Gore \& Associates, Inc. rounded to two significant figures; MDL, method detection level; $\mu$ g, micrograms; Sampler 662559, example of unique identification number assigned by W.L. Gore \& Associates to passive sampler; N/A, not applicable; nd, not detected; E, the reported value for a combined mass should be considered estimated if the masses of any of the individual compounds used to calculate the combined mass were reported as below detection level; bdl, below detection level; a value of 0.00 (reporting format of W.L. Gore \& Associates, Inc.) is reported for a combined mass if the individual compounds included in the combined mass were not detected above method detection levels and at least one of the individual compounds was reported as below detection level]

\begin{tabular}{|c|c|c|c|c|c|c|c|c|c|c|c|c|}
\hline \multirow{2}{*}{$\begin{array}{c}\text { Organic } \\
\text { compounds }\end{array}$} & \multirow{2}{*}{$\begin{array}{l}\text { MDL } \\
(\mu g)\end{array}$} & \multicolumn{11}{|c|}{ Sampler } \\
\hline & & 667405 & 667406 & 667407 & 667408 & 667409 & 667410 & 667411 & 667412 & 667413 & 667414 & 667415 \\
\hline Total petroleum hydrocarbon (TPH) & 0.02 & 0.82 & 0.76 & 1.9 & 0.23 & 13 & 6.6 & 7.4 & 0.20 & 0.11 & 0.73 & 0.19 \\
\hline BTEX (gasoline) $)^{1}$ & N/A & nd & nd & nd & nd & nd & 0.85 & 0.06 & nd & nd & nd & nd \\
\hline Benzene & 0.01 & nd & nd & nd & nd & nd & nd & nd & nd & nd & nd & nd \\
\hline Toluene & 0.01 & nd & nd & nd & nd & nd & 0.85 & 0.06 & nd & nd & nd & nd \\
\hline Ethylbenzene & 0.02 & nd & nd & nd & nd & nd & nd & nd & nd & nd & nd & nd \\
\hline meta- and para-Xylene & 0.02 & nd & nd & nd & nd & nd & nd & nd & nd & nd & nd & nd \\
\hline ortho-Xylene, & 0.01 & nd & nd & nd & nd & nd & nd & nd & nd & nd & nd & nd \\
\hline $\mathrm{C}_{11}, \mathrm{C}_{13}$, and $\mathrm{C}_{15}(\text { diesel })^{1}$ & $\mathrm{~N} / \mathrm{A}$ & nd & nd & 0.02 & nd & 0.12 & E0.15 & 0.24 & nd & nd & E0.02 & nd \\
\hline Undecane & 0.01 & nd & nd & 0.02 & nd & 0.10 & 0.15 & 0.22 & nd & nd & 0.02 & nd \\
\hline Tridecane & 0.01 & nd & nd & nd & nd & 0.02 & bdl & 0.02 & nd & nd & bdl & nd \\
\hline Pentadecane & 0.01 & nd & nd & nd & nd & nd & nd & nd & nd & nd & bdl & nd \\
\hline Octane & 0.02 & bdl & nd & nd & nd & nd & 0.07 & nd & nd & nd & nd & nd \\
\hline Methyl tert-butyl ether & 0.03 & nd & nd & nd & nd & nd & nd & nd & nd & nd & nd & nd \\
\hline Trimethylbenzene ${ }^{1}$ & $\mathrm{~N} / \mathrm{A}$ & nd & nd & nd & nd & nd & nd & nd & nd & nd & nd & nd \\
\hline 1,2,4-Trimethylbenzene & 0.01 & nd & nd & nd & nd & nd & nd & nd & nd & nd & nd & nd \\
\hline 1,3,5-Trimethylbenzene & 0.02 & nd & nd & nd & nd & nd & nd & nd & nd & nd & nd & nd \\
\hline 1,2-Dichlorobenzene & 0.01 & nd & nd & nd & nd & nd & nd & nd & nd & nd & nd & nd \\
\hline 1,3-Dichlorobenzene & 0.01 & nd & nd & nd & nd & nd & nd & nd & nd & nd & nd & nd \\
\hline 1,4-Dichlorobenzene & 0.01 & nd & nd & nd & nd & nd & nd & nd & nd & nd & nd & nd \\
\hline Chlorobenzene & 0.03 & nd & nd & nd & nd & nd & nd & nd & nd & nd & nd & nd \\
\hline Chloroform & 0.01 & nd & nd & nd & nd & nd & nd & nd & nd & nd & nd & nd \\
\hline cis- and trans-1,2-Dichloroethene $^{1}$ & N/A & nd & nd & nd & nd & nd & nd & nd & nd & nd & nd & nd \\
\hline trans-1,2-Dichloroethene & 0.05 & nd & nd & nd & nd & nd & nd & nd & nd & nd & nd & nd \\
\hline cis-1,2-Dichloroethene & 0.02 & nd & nd & nd & nd & nd & nd & nd & nd & nd & nd & nd \\
\hline Trichloroethene & 0.02 & nd & nd & nd & nd & nd & nd & nd & nd & nd & nd & nd \\
\hline Perchloroethene & 0.02 & nd & nd & nd & nd & nd & nd & nd & nd & nd & nd & nd \\
\hline 1,1-Dichloroethane & 0.02 & nd & nd & nd & nd & nd & nd & nd & nd & nd & nd & nd \\
\hline 1,2-Dichloroethane & 0.01 & nd & nd & nd & nd & nd & nd & nd & nd & nd & nd & nd \\
\hline 1,1,1-Trichloroethane & 0.01 & nd & nd & nd & nd & nd & nd & nd & nd & nd & nd & nd \\
\hline 1,1,2-Trichloroethane & 0.02 & nd & nd & nd & nd & nd & nd & nd & nd & nd & nd & nd \\
\hline $1,1,1,2$-Tetrachloroethane & 0.02 & nd & nd & nd & nd & nd & nd & nd & nd & nd & nd & nd \\
\hline 1,1,2,2-Tetrachloroethane & 0.01 & nd & nd & nd & nd & nd & nd & nd & nd & nd & nd & nd \\
\hline Carbon tetrachloride & 0.03 & nd & nd & nd & nd & nd & nd & nd & nd & nd & nd & nd \\
\hline Naphthalene and 2-Methyl naphthalene ${ }^{1}$ & $\mathrm{~N} / \mathrm{A}$ & nd & nd & nd & nd & 0.02 & nd & 0.00 & nd & nd & nd & nd \\
\hline Naphthalene & 0.01 & nd & nd & nd & nd & 0.02 & nd & bdl & nd & nd & nd & nd \\
\hline 2-Methyl naphthalene & 0.01 & nd & nd & nd & nd & nd & nd & nd & nd & nd & nd & nd \\
\hline
\end{tabular}


Table 2. Masses of volatile and semivolatile organic compounds and polycyclic aromatic hydrocarbons detected in passive samplers deployed and recovered during the soil-gas assessment in the Gibson Road landfill study area, Fort Gordon, Georgia, July 25-29, July 26-29, and July 29-August 3, 2011. - Continued

[Raw data provided by W.L. Gore \& Associates, Inc. rounded to two significant figures; MDL, method detection level; $\mu \mathrm{g}$, micrograms; Sampler 662559, example of unique identification number assigned by W.L. Gore \& Associates to passive sampler; N/A, not applicable; nd, not detected; E, the reported value for a combined mass should be considered estimated if the masses of any of the individual compounds used to calculate the combined mass were reported as below detection level; bdl, below detection level; a value of 0.00 (reporting format of W.L. Gore \& Associates, Inc.) is reported for a combined mass if the individual compounds included in the combined mass were not detected above method detection levels and at least one of the individual compounds was reported as below detection level]

\begin{tabular}{|c|c|c|c|c|c|c|c|c|c|c|c|c|}
\hline \multirow{2}{*}{$\begin{array}{l}\text { Organic } \\
\text { compounds }\end{array}$} & \multirow{2}{*}{$\begin{array}{l}\text { MDL } \\
(\mu \mathrm{g})\end{array}$} & \multicolumn{11}{|c|}{ Sampler } \\
\hline & & 667416 & 667417 & 667418 & 667419 & 667420 & 667421 & 667422 & 667423 & 667424 & 667425 & 667426 \\
\hline Total petroleum hydrocarbon (TPH) & 0.02 & 0.56 & 0.21 & 0.20 & 0.19 & 0.35 & 5.0 & 27.0 & 0.43 & 0.89 & 1.7 & 0.49 \\
\hline BTEX (gasoline) ${ }^{1}$ & N/A & 0.05 & nd & nd & nd & nd & nd & nd & nd & nd & nd & nd \\
\hline Benzene & 0.01 & nd & nd & nd & nd & nd & nd & nd & nd & nd & nd & nd \\
\hline Toluene & 0.01 & 0.05 & nd & nd & nd & nd & nd & nd & nd & nd & nd & nd \\
\hline Ethylbenzene & 0.02 & nd & nd & nd & nd & nd & nd & nd & nd & nd & nd & nd \\
\hline meta- and para-Xylene & 0.02 & nd & nd & nd & nd & nd & nd & nd & nd & nd & nd & nd \\
\hline ortho-Xylene, & 0.01 & nd & nd & nd & nd & nd & nd & nd & nd & nd & nd & nd \\
\hline $\mathrm{C}_{11}, \mathrm{C}_{13}$, and $\mathrm{C}_{15}(\text { diesel })^{1}$ & N/A & 0.00 & nd & 0.02 & 0.01 & nd & E0.06 & nd & nd & E0.02 & E0.01 & 0.00 \\
\hline Undecane & 0.01 & bdl & nd & nd & 0.01 & nd & 0.04 & nd & nd & 0.02 & bdl & bdl \\
\hline Tridecane & 0.01 & nd & nd & 0.02 & nd & nd & bdl & nd & nd & bdl & 0.01 & nd \\
\hline Pentadecane & 0.01 & nd & nd & nd & nd & nd & 0.02 & nd & nd & nd & nd & bdl \\
\hline Octane & 0.02 & nd & nd & nd & nd & nd & nd & nd & nd & nd & nd & nd \\
\hline Methyl tert-butyl ether & 0.03 & nd & nd & nd & nd & nd & nd & nd & nd & nd & nd & nd \\
\hline Trimethylbenzene $^{1}$ & N/A & nd & nd & nd & nd & nd & nd & nd & nd & nd & nd & nd \\
\hline 1,2,4-Trimethylbenzene & 0.01 & nd & nd & nd & nd & nd & nd & nd & nd & nd & nd & nd \\
\hline 1,3,5-Trimethylbenzene & 0.02 & nd & nd & nd & nd & nd & nd & nd & nd & nd & nd & nd \\
\hline 1,2-Dichlorobenzene & 0.01 & nd & nd & nd & nd & nd & nd & nd & nd & nd & nd & nd \\
\hline 1,3-Dichlorobenzene & 0.01 & nd & nd & nd & nd & nd & nd & nd & nd & nd & nd & nd \\
\hline 1,4-Dichlorobenzene & 0.01 & nd & nd & nd & nd & nd & nd & nd & nd & nd & nd & nd \\
\hline Chlorobenzene & 0.03 & nd & nd & nd & nd & nd & nd & nd & nd & nd & nd & nd \\
\hline Chloroform & 0.01 & nd & nd & nd & nd & nd & nd & nd & nd & nd & nd & nd \\
\hline cis- and trans-1,2-Dichloroethene $^{1}$ & $\mathrm{~N} / \mathrm{A}$ & nd & nd & nd & nd & nd & nd & nd & nd & nd & nd & nd \\
\hline trans-1,2-Dichloroethene & 0.05 & nd & nd & nd & nd & nd & nd & nd & nd & nd & nd & nd \\
\hline cis-1,2-Dichloroethene & 0.02 & nd & nd & nd & nd & nd & nd & nd & nd & nd & nd & nd \\
\hline Trichloroethene & 0.02 & nd & nd & nd & nd & nd & nd & nd & nd & nd & nd & nd \\
\hline Perchloroethene & 0.02 & nd & nd & nd & nd & nd & nd & nd & nd & nd & nd & nd \\
\hline 1,1-Dichloroethane & 0.02 & nd & nd & nd & nd & nd & nd & nd & nd & nd & nd & nd \\
\hline 1,2-Dichloroethane & 0.01 & nd & nd & nd & nd & nd & nd & nd & nd & nd & nd & nd \\
\hline 1,1,1-Trichloroethane & 0.01 & nd & nd & nd & nd & nd & nd & nd & nd & nd & nd & nd \\
\hline 1,1,2-Trichloroethane & 0.02 & nd & nd & nd & nd & nd & nd & nd & nd & nd & nd & nd \\
\hline $1,1,1,2$-Tetrachloroethane & 0.02 & nd & nd & nd & nd & nd & nd & nd & nd & nd & nd & nd \\
\hline 1,1,2,2-Tetrachloroethane & 0.01 & nd & nd & nd & nd & nd & nd & nd & nd & nd & nd & nd \\
\hline Carbon tetrachloride & 0.03 & nd & nd & nd & nd & nd & nd & nd & nd & nd & nd & nd \\
\hline Naphthalene and 2-Methyl naphthalene ${ }^{1}$ & N/A & nd & nd & nd & nd & nd & nd & nd & nd & nd & nd & nd \\
\hline Naphthalene & 0.01 & nd & nd & nd & nd & nd & nd & nd & nd & nd & nd & nd \\
\hline 2-Methyl naphthalene & 0.01 & nd & nd & nd & nd & nd & nd & nd & nd & nd & nd & nd \\
\hline
\end{tabular}


Table 2. Masses of volatile and semivolatile organic compounds and polycyclic aromatic hydrocarbons detected in passive samplers deployed and recovered during the soil-gas assessment in the Gibson Road landfill study area, Fort Gordon, Georgia, July 25-29, July 26-29, and July 29-August 3, 2011. - Continued

[Raw data provided by W.L. Gore \& Associates, Inc. rounded to two significant figures; MDL, method detection level; $\mu$ g, micrograms; Sampler 662559, example of unique identification number assigned by W.L. Gore \& Associates to passive sampler; N/A, not applicable; nd, not detected; E, the reported value for a combined mass should be considered estimated if the masses of any of the individual compounds used to calculate the combined mass were reported as below detection level; bdl, below detection level; a value of 0.00 (reporting format of W.L. Gore \& Associates, Inc.) is reported for a combined mass if the individual compounds included in the combined mass were not detected above method detection levels and at least one of the individual compounds was reported as below detection level]

\begin{tabular}{|c|c|c|c|c|c|c|c|c|c|c|}
\hline \multirow{2}{*}{$\begin{array}{c}\text { Organic } \\
\text { compounds }\end{array}$} & \multirow{2}{*}{$\begin{array}{l}\text { MDL } \\
(\mu \mathrm{g})\end{array}$} & \multirow{2}{*}{$\begin{array}{c}\text { Sampler } \\
667427\end{array}$} & \multicolumn{5}{|c|}{ Trip blank } & \multirow{2}{*}{\multicolumn{3}{|c|}{ Laboratory method blank }} \\
\hline & & & 667428 TB & 667429 TB & 667430 TB & 667431 TB & 667432 TB & & & \\
\hline Total petroleum hydrocarbon (TPH) & 0.02 & 0.61 & nd & nd & nd & nd & nd & nd & nd & nd \\
\hline BTEX (gasoline) $)^{1}$ & $\mathrm{~N} / \mathrm{A}$ & nd & nd & nd & nd & nd & nd & nd & nd & nd \\
\hline Benzene & 0.01 & nd & nd & nd & nd & nd & nd & nd & nd & nd \\
\hline Toluene & 0.01 & nd & nd & nd & nd & nd & nd & nd & nd & nd \\
\hline Ethylbenzene & 0.02 & nd & nd & nd & nd & nd & nd & nd & nd & nd \\
\hline meta- and para-Xylene & 0.02 & nd & nd & nd & nd & nd & nd & nd & nd & nd \\
\hline ortho-Xylene, & 0.01 & nd & nd & nd & nd & nd & nd & nd & nd & nd \\
\hline $\mathrm{C}_{11}, \mathrm{C}_{13}$, and $\mathrm{C}_{15}(\text { diesel })^{1}$ & N/A & E0.02 & nd & nd & nd & nd & nd & nd & nd & nd \\
\hline Undecane & 0.01 & 0.02 & nd & nd & nd & nd & nd & nd & nd & nd \\
\hline Tridecane & 0.01 & nd & nd & nd & nd & nd & nd & nd & nd & nd \\
\hline Pentadecane & 0.01 & bdl & nd & nd & nd & nd & nd & nd & nd & nd \\
\hline Octane & 0.02 & nd & nd & nd & nd & nd & nd & nd & nd & nd \\
\hline Methyl tert-butyl ether & 0.03 & nd & nd & nd & nd & nd & nd & nd & nd & nd \\
\hline Trimethylbenzene $^{1}$ & $\mathrm{~N} / \mathrm{A}$ & nd & nd & nd & nd & nd & nd & nd & nd & nd \\
\hline $1,2,4$-Trimethylbenzene & 0.01 & nd & nd & nd & nd & nd & nd & nd & nd & nd \\
\hline 1,3,5-Trimethylbenzene & 0.02 & nd & nd & nd & nd & nd & nd & nd & nd & nd \\
\hline 1,2-Dichlorobenzene & 0.01 & nd & nd & nd & nd & nd & nd & nd & nd & nd \\
\hline 1,3-Dichlorobenzene & 0.01 & nd & nd & nd & nd & nd & nd & nd & nd & nd \\
\hline 1,4-Dichlorobenzene & 0.01 & nd & nd & nd & nd & nd & nd & nd & nd & nd \\
\hline Chlorobenzene & 0.03 & nd & nd & nd & nd & nd & nd & nd & nd & nd \\
\hline Chloroform & 0.01 & nd & nd & nd & nd & nd & nd & nd & nd & nd \\
\hline cis- and trans-1,2-Dichloroethene $^{1}$ & $\mathrm{~N} / \mathrm{A}$ & nd & nd & nd & nd & nd & nd & nd & nd & nd \\
\hline trans-1,2-Dichloroethene & 0.05 & nd & nd & nd & nd & nd & nd & nd & nd & nd \\
\hline cis-1,2-Dichloroethene & 0.02 & nd & nd & nd & nd & nd & nd & nd & nd & nd \\
\hline Trichloroethene & 0.02 & nd & nd & nd & nd & nd & nd & nd & nd & nd \\
\hline Perchloroethene & 0.02 & nd & nd & nd & nd & nd & nd & nd & nd & nd \\
\hline 1,1-Dichloroethane & 0.02 & nd & nd & nd & nd & nd & nd & nd & nd & nd \\
\hline 1,2-Dichloroethane & 0.01 & nd & nd & nd & nd & nd & nd & nd & nd & nd \\
\hline 1,1,1-Trichloroethane & 0.01 & nd & nd & nd & nd & nd & nd & nd & nd & nd \\
\hline 1,1,2-Trichloroethane & 0.02 & nd & nd & nd & nd & nd & nd & nd & nd & nd \\
\hline 1,1,1,2-Tetrachloroethane & 0.02 & nd & nd & nd & nd & nd & nd & nd & nd & nd \\
\hline 1,1,2,2-Tetrachloroethane & 0.01 & nd & nd & nd & nd & nd & nd & nd & nd & nd \\
\hline Carbon tetrachloride & 0.03 & nd & nd & nd & nd & nd & nd & nd & nd & nd \\
\hline Naphthalene and 2-Methyl naphthalene ${ }^{1}$ & $\mathrm{~N} / \mathrm{A}$ & nd & nd & nd & nd & nd & nd & nd & nd & nd \\
\hline Naphthalene & 0.01 & nd & nd & nd & nd & nd & nd & nd & nd & nd \\
\hline 2-Methyl naphthalene & 0.01 & nd & nd & nd & nd & nd & nd & nd & nd & nd \\
\hline
\end{tabular}

${ }^{1}$ Combined mass of two or more compounds with no method detection level provided by laboratory. 
Table 3. Concentrations of volatile and semivolatile organic compounds and polycyclic aromatic hydrocarbons detected in passive samplers deployed and recovered in the water column of monitoring wells in Gibson Road landfill study area, Fort Gordon, Georgia, August 8, 2011.

[Data as provided by W.L. Gore \& Associates, Inc.; MDL, method detection level; $\mu \mathrm{g} / \mathrm{L}$, micrograms per liter; Sampler 667443, example of unique identification number assigned by W.L. Gore \& Associates to each soil-gas sampler; N/A, not applicable; nd, not detected]

\begin{tabular}{|c|c|c|c|c|c|c|c|}
\hline \multirow{2}{*}{$\begin{array}{l}\text { Organic } \\
\text { compound }\end{array}$} & \multirow{2}{*}{$\begin{array}{c}\text { MDL } \\
(\mu \mathrm{g} / \mathrm{L})\end{array}$} & \multicolumn{6}{|c|}{ Sampler } \\
\hline & & 667433 & 667434 & 667435 & 667436 & 667437 & 667438 \\
\hline Total petroleum hydrocarbon (TPH) & 8.3 & 220 & 320 & 110 & 56 & 18 & 330 \\
\hline BTEX (gasoline) ${ }^{1}$ & N/A & nd & 6.1 & nd & nd & 27 & nd \\
\hline Benzene & 4.1 & nd & 6.1 & nd & nd & 27 & nd \\
\hline Toluene & 4.1 & nd & nd & nd & nd & nd & nd \\
\hline Ethylbenzene & 8.3 & nd & nd & nd & nd & nd & nd \\
\hline meta- and para-Xylene & 8.3 & nd & nd & nd & nd & nd & nd \\
\hline ortho-Xylene, & 4.1 & nd & nd & nd & nd & nd & nd \\
\hline $\mathrm{C}_{11}, \mathrm{C}_{13}$, and $\mathrm{C}_{15}(\text { diesel })^{1}$ & $\mathrm{~N} / \mathrm{A}$ & 0.00 & 0.00 & 0.00 & nd & nd & nd \\
\hline Undecane & 4.1 & nd & bdl & nd & nd & nd & nd \\
\hline Tridecane & 4.1 & bdl & nd & bdl & nd & nd & nd \\
\hline Pentadecane & 4.1 & bdl & nd & bdl & nd & nd & nd \\
\hline Octane & 8.3 & nd & nd & nd & nd & nd & nd \\
\hline Methyl tert-butyl ether & 25 & nd & nd & nd & nd & nd & nd \\
\hline Trimethylbenzene $e^{1}$ & N/A & nd & 0.00 & nd & nd & nd & nd \\
\hline 1,2,4-Trimethylbenzene & 4.1 & nd & bdl & nd & nd & nd & nd \\
\hline 1,3,5-Trimethylbenzene & 8.2 & nd & bdl & nd & nd & nd & nd \\
\hline 1,2-Dichlorobenzene & 4.1 & nd & nd & nd & nd & nd & nd \\
\hline 1,3-Dichlorobenzene & 4.1 & nd & nd & nd & nd & nd & nd \\
\hline 1,4-Dichlorobenzene & 4.1 & nd & 4.2 & nd & nd & nd & nd \\
\hline Chlorobenzene & 12 & nd & nd & nd & nd & nd & nd \\
\hline Chloroform & 4 & nd & nd & nd & 22 & nd & nd \\
\hline cis- and trans-1,2-Dichloroethene $^{1}$ & N/A & nd & 0.00 & 13 & nd & nd & nd \\
\hline trans-1,2-Dichloroethene & 24 & nd & nd & nd & nd & nd & nd \\
\hline cis-1,2-Dichloroethene & 8.5 & nd & bdl & 13 & nd & nd & nd \\
\hline Trichloroethene & 8.3 & nd & 8.6 & 49 & bdl & nd & nd \\
\hline Perchloroethene & 8.3 & nd & 9.8 & 54 & 13 & nd & nd \\
\hline 1,1-Dichloroethane & 8.3 & nd & 140 & 1,300 & 220 & 42 & nd \\
\hline 1,2-Dichloroethane & 4.1 & nd & nd & nd & nd & nd & nd \\
\hline 1,1,1-Trichloroethane & 4.1 & nd & nd & 8.2 & nd & nd & nd \\
\hline 1,1,2-Trichloroethane & 8.3 & nd & nd & nd & nd & nd & nd \\
\hline 1,1,1,2-Tetrachloroethane & 8.3 & nd & nd & nd & nd & nd & nd \\
\hline 1,1,2,2-Tetrachloroethane & 4.1 & nd & nd & nd & nd & nd & nd \\
\hline Carbon tetrachloride & 12 & nd & nd & nd & nd & nd & nd \\
\hline Naphthalene and 2-Methyl naphthalene ${ }^{1}$ & $\mathrm{~N} / \mathrm{A}$ & nd & E14 & nd & nd & nd & nd \\
\hline Naphthalene & 4.13 & nd & 14 & nd & nd & nd & nd \\
\hline 2-Methyl naphthalene & 4.13 & nd & bdl & nd & nd & nd & nd \\
\hline
\end{tabular}


Table 3. Concentrations of volatile and semivolatile organic compounds and polycyclic aromatic hydrocarbons detected in passive samplers deployed and recovered in the water column of monitoring wells in Gibson Road landfill study area, Fort Gordon, Georgia, August 8, 2011. - Continued

[Data as provided by W.L. Gore \& Associates, Inc.; MDL, method detection level; $\mu \mathrm{g} / \mathrm{L}$, micrograms per liter; Sampler 667443, example of unique identification number assigned by W.L. Gore \& Associates to each soil-gas sampler; N/A, not applicable; nd, not detected]

\begin{tabular}{|c|c|c|c|c|c|c|c|}
\hline \multirow{2}{*}{ Organic compound } & \multirow{2}{*}{$\begin{array}{l}\text { MDL } \\
(\mu \mathrm{g} / \mathrm{L})\end{array}$} & \multicolumn{3}{|c|}{ Sampler } & \multicolumn{2}{|c|}{ Trip blank } & \multirow{2}{*}{$\begin{array}{c}\text { Method } \\
\text { blank }\end{array}$} \\
\hline & & 667439 & 667440 & 667441 & 667442 & 667443 & \\
\hline Total petroleum hydrocarbon (TPH) & 8.3 & 170 & 320 & 31 & bdl & bdl & nd \\
\hline BTEX (gasoline) $^{1}$ & N/A & nd & 37 & nd & nd & 4.8 & nd \\
\hline Benzene & 4.1 & nd & 37 & nd & nd & nd & nd \\
\hline Toluene & 4.1 & nd & nd & nd & nd & 4.8 & nd \\
\hline Ethylbenzene & 8.3 & nd & nd & nd & nd & nd & nd \\
\hline meta- and para-Xylene & 8.3 & nd & nd & nd & nd & nd & nd \\
\hline ortho-Xylene, & 4.1 & nd & nd & nd & nd & nd & nd \\
\hline $\mathrm{C}_{11}, \mathrm{C}_{13}$, and $\mathrm{C}_{15}(\text { diesel })^{1}$ & N/A & 0.00 & nd & 0.00 & nd & nd & nd \\
\hline Undecane & 4.1 & nd & nd & nd & nd & nd & nd \\
\hline Tridecane & 4.1 & nd & nd & nd & nd & nd & nd \\
\hline Pentadecane & 4.1 & bdl & nd & bdl & nd & nd & nd \\
\hline Octane & 8.3 & nd & nd & nd & nd & nd & nd \\
\hline Methyl tert-butyl ether & 25 & nd & nd & nd & nd & nd & nd \\
\hline Trimethylbenzene $^{1}$ & N/A & nd & nd & nd & nd & nd & nd \\
\hline 1,2,4-Trimethylbenzene & 4.1 & nd & nd & nd & nd & nd & nd \\
\hline 1,3,5-Trimethylbenzene & 8.2 & nd & nd & nd & nd & nd & nd \\
\hline 1,2-Dichlorobenzene & 4.1 & nd & nd & nd & nd & nd & nd \\
\hline 1,3-Dichlorobenzene & 4.1 & nd & nd & nd & nd & nd & nd \\
\hline 1,4-Dichlorobenzene & 4.1 & nd & nd & nd & nd & nd & nd \\
\hline Chlorobenzene & 12 & nd & nd & nd & nd & nd & nd \\
\hline Chloroform & 4 & nd & nd & nd & nd & nd & nd \\
\hline cis- and trans-1,2-Dichloroethene ${ }^{1}$ & $\mathrm{~N} / \mathrm{A}$ & nd & nd & nd & nd & nd & nd \\
\hline trans-1,2-Dichloroethene & 24 & nd & nd & nd & nd & nd & nd \\
\hline cis-1,2-Dichloroethene & 8.5 & nd & nd & nd & nd & nd & nd \\
\hline Trichloroethene & 8.3 & nd & nd & nd & nd & nd & nd \\
\hline Perchloroethene & 8.3 & nd & nd & nd & nd & nd & nd \\
\hline 1,1-Dichloroethane & 8.3 & nd & nd & nd & nd & nd & nd \\
\hline 1,2-Dichloroethane & 4.1 & nd & nd & nd & nd & nd & nd \\
\hline 1,1,1-Trichloroethane & 4.1 & nd & nd & nd & nd & nd & nd \\
\hline 1,1,2-Trichloroethane & 8.3 & nd & nd & nd & nd & nd & nd \\
\hline 1,1,1,2-Tetrachloroethane & 8.3 & nd & nd & nd & nd & nd & nd \\
\hline 1,1,2,2-Tetrachloroethane & 4.1 & nd & nd & nd & nd & nd & nd \\
\hline Carbon tetrachloride & 12 & nd & nd & nd & nd & nd & nd \\
\hline Naphthalene and 2-Methyl naphthalene ${ }^{1}$ & $\mathrm{~N} / \mathrm{A}$ & nd & nd & nd & nd & nd & nd \\
\hline Naphthalene & 4.13 & nd & nd & nd & nd & nd & nd \\
\hline 2-Methyl naphthalene & 4.13 & nd & nd & nd & nd & nd & nd \\
\hline
\end{tabular}

${ }^{1}$ Combined concentrations of two or more compounds with no method detection level provided by laboratory. 
Prepared by:

USGS Publishing Network

Raleigh Publishing Service Center

3916 Sunset Ridge Road

Raleigh, NC 27607

For additional information regarding this publication, contact: USGS South Carolina Water Science Center

Stephenson Center, Suite 129

720 Gracern Road

Columbia, SC 29210-7651

Or visit the USGS South Carolina Water Science Center Web site at: http://sc.water.usgs.gov 



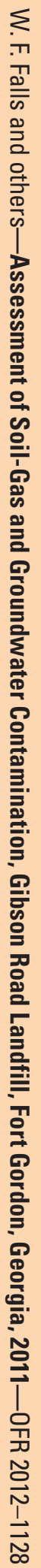

